\title{
Investigating the Antibiotic Resistance Prevalence and Phenotypic and Genotypic Evaluation of AcrAB-OprM Efflux Pump in Multidrug-resistant in Clinical Isolates of Moraxella catarrhalis in Kazerun City, Iran
}

\author{
Parvin Mohammad Shafiei ${ }^{1}$, Majid Baserisalehi ${ }^{1 *}$ (D) Sina Mobasherizadeh ${ }^{2}$
}

1. Department of Microbiology, Faculty of Science, Islamic Azad University, Kazeroun, Iran

2. Hospital Infection Research Center, Isfahan University of Medical Sciences, Isfahan, Iran

\section{ABSTRACT}

Background: Moraxella catarrhalis a gram-negative bacterium, is a significant cause of lower and upper respiratory infections. The RND family efflux pumps lead to multidrug resistance in gram-negative bacteria. One of the well-known pumps in $M$. catarrhalis is AcrAB-OprM system. This study aimed to investigate the antibiotic resistance in $M$. catarrhalis and to determine its antibiotic resistance dependence on the efflux pump.

Methods: In this study, 137 different clinical samples were collected. M. catarrhalis isolates were confirmed by biochemical assays and PCR. The antibiotic susceptibility pattern was investigated by disc diffusion method according to CLSI. Phenotypic study of the efflux pumps activity was done using cartwheel method. Study of the acra, acrb, and oprm genes were performed by, PCR. In addition, the association of efflux pump with antibiotic resistance was investigated using phenylalanine-arginine $\beta$-naphthylamide.

Results: Of 10 isolated M. catarrhalis, 70\% (7 isolates) showed multiple antibiotic resistance. The resistance to cefazolin, ceftazidime, tetracycline, chloramphenicol, and ciprofloxacin antibiotics was also dependent on the efflux pump.

Conclusion: The results showed that multiple antibiotic resistance has increased in Moraxella catarrhalis. The $70 \%$ presence of $a c r a, a c r b$, oprm efflux genes of the efflux pumps in this bacterium and antibiotic resistance reduction in the presence of efflux pump inhibitor shows the importance of examining these genes' presence to suggest a suitable treatment model for the patients infected with $M$. catarrhalis.

Keywords: acra, acrb, Efflux Pump, Moraxella catarrhalis, Multidrug resistance, oprm, PAßN

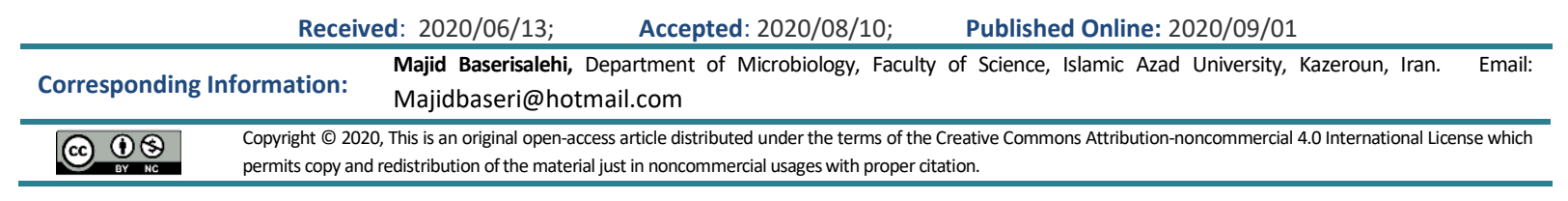

Use your device to scan and read the article online

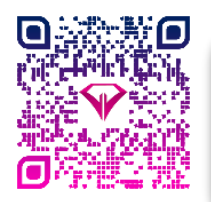

Mohammad Shafiei P, Baserisalehi M, Mobasherizade S. Investigating the Antibiotic Resistance Prevalence and Phenotypic and Genotypic Evaluation of AcrAB-OprM Efflux Pump in Multidrugresistant in Clinical Isolates of Moraxella catarrhalis in Kazerun City, Iran. Iran J Med Microbiol. 2020; 14 (5) :388-407

Download citation: BibTeX | RIS | EndNote | Medlars | ProCite | Reference Manager | RefWorks

Send citation to: $\%$ Mendeley $\mathbf{Z}$ Zotero ${ }_{\text {RefWorks }}$ 


\section{Introduction}

Moraxella catarrhalis is a non-motile and nonpigmented gram-negative diplococcus considered as a nonpathogenic bacteria and respiratory system normal flora up until 1995, however; recognized as a human pathogenic agent afterwards (1). These bacteria can cause upper and lower respiratory tract infections in adults (1-3). Subsequent to Streptococcus pneumoniae and Haemophilus influenzae, M. catarrhalis is a leading bacterial infection agent responsible for $15 \%$ to $20 \%$ of the cases (4).

Due to their broad innate and induced resistance to numerous antibiotic families, treating such respiratory infections is troublesome for medical practitioners (3). These bacteria are known for their exclusive innate antibiotic resistance and very likely acquired antibiotic resistance (5). Antibiotic resistance has led to several difficulties $M$. catarrhalis infection treatment.

Innate resistance in the bacteria can be on account of drug enzyme inhibition such as inhibition of betalactamase which transforms $\beta$-lactam using hydrolysis, bacteria cell membrane permeability alteration which leads to drug resistance such as purines, and expressing active secretion systems or efflux pumps (5). Due to their broad substrate variety, efflux pumps in this family have been divided into five grand groups including RND (Division Nodulation Resistance) multidrug efflux pumps (6).

AcrAB-OprM is an efflux system of RND family in $M$. catarrhalis. The pump consists of an inner membrane pump (AcrB), an outer membrane channel (OprM), and a periplasmic adaptor protein (AcrA) that facilitates outer and inner membrane antibiotic transmission in the bacteria. As AcrAB-OprM substrates, drugs can elevate acrAB-oprM expression which can lead to multidrug resistance (5).

Efflux pumps not only increase minimal inhibition concentration (MIC) of antibiotics, but also develop drug-resistant lineages using proton motive force (PMF) and decreasing drug concentration $(7,8)$. With increasing efflux pump expression, these bacteria resist to a wide range of drugs. Their synergism with other drug resistance mechanisms is of great importance and should be studied like other resistance mechanisms (810). Recognition and inhibition of efflux pumps seem promising reinforcements for antibacterial substances efficacy. In the recent years, numerous inhibitors including natural products, various antibiotics, and synthetic molecules have been tested on gram positive and gram-negative bacteria in order to solve the resistance problem (11). Considering the everincreasing bacterial resistance, and the outstanding role efflux pumps play in it, discovering resistance adjusting factors or more specifically, efflux pump inhibitors (EPIs) is of great importance so that designing novel drugs necessitates recognizing and understanding resistance inducing systems in efflux pumps $(8,9,11)$.

Increasing antibiotic resistance in the bacteria is a global infectious and respiratory diseases risk. According to the absence of phenotypic and genotypic studies on the role of efflux pumps in $M$. catarrhalis infection resistance in Iran, this study aims to assess phenotypic and genotypic prevalence of acrAB-oprM efflux pump genes as significant antibiotic resistance agents in $M$. catarrhalis and inhibit efflux pumps using phenylalanine-arginine $\beta$-naphthylamide $(\mathrm{Pa} \beta \mathrm{N})$ as a clinical practice.

\section{Materials and Methods}

\section{Sampling and Identification of Bacteria}

In this cross-sectional descriptive study, sampling was done on patients aged 3-75 years, both male and female, with respiratory infections and pneumonia referred to Bagherul Uloom clinic and laboratory and Valiasr Hospital clinic in Kazerun from December 2015 to May 2016. Inclusion criteria were patients referred for suspected tuberculosis, samples with respiratory infections, adult smokers with chronic bronchitis and sinusitis and children with acute middle ear infection. The above identification was made by a specialist.

Finally, 137 samples of sputum and throat swab (oral and laryngeal pharynx), and purulent secretions of the middle ear taken under standard conditions, were transferred to the laboratory. Samples were cultured in the laboratory for $24 \mathrm{~h}$ on chocolate agar and blood agar (Merck-Germany) growth mediums. Standard microbiological and biochemical tests to differentiate bacteria, including gram staining, oxidase, catalase, DNase, the glucose fermentation test (glucose, sucrose, maltose, fructose, and lactose), and nitrate reduction were used to identify and isolate M. catarrhalis bacteria (12).

\section{Determination of Antibiotic Susceptibility by Kirby- Bauer Method}

The pattern of antibiotic susceptibility in the strains obtained using the disk diffusion method (KirbyBauer) was investigated in accordance with the guidelines of the CLSI (Clinical and Laboratory Standards Institute) version 2016.

Turbidity equivalent to 0.5 McFarland tube was prepared and then cultured on the Mueller-HintonAgar growth medium (Merck, Germany) for $24 \mathrm{~h}$ and then antibiotic disks (Padtan Teb, Iran) were placed on the growth medium. Antibiotic resistance to penicillin $(10 \mu \mathrm{g})$, ampicillin $(10 \mu \mathrm{g})$, erythromycin $(15 \mu \mathrm{g})$, chloramphenicol (30 $\mu \mathrm{g})$, clarithromycin (15 micrograms), cefazolin $(30 \mu \mathrm{g})$, coamoxyclav $(10+20$ $\mu \mathrm{g})$, trimethoprim-sulfamethoxazole (1.25-23.75 $\mu \mathrm{g})$, 
tetracycline $(30 \mu \mathrm{g})$, ciprofloxacin $(15 \mu \mathrm{g})$, azithromycin $(15 \mu \mathrm{g})$, amikacin $(30 \mu \mathrm{g})$, gentamicin $(10$ $\mu \mathrm{g})$ and ceftazidime (30 $\mathrm{\mu g}$ ) (Himedia, India) was investigated. After $24 \mathrm{~h}$ at $37^{\circ} \mathrm{C}$, the diameter of the growth inhibition zone around the discs were measured and the strains were divided into susceptible, semi-susceptible, and resistant groups according to the CLSI guidelines. Isolates that showed resistance to more than two classes of antibiotics were introduced as strains with multiple MDR resistance (13).

\section{Identification of Moraxella catarrhalis by PCR}

Identifying $M$. catarrhalis with multidrug resistance was confirmed by the SrRNA16 sequence (Table 1). DNA of these samples was extracted by Kit (Yekta Tajhiz, Iran). PCR reaction was performed on a final volume of $25 \mu \mathrm{L}$ including $18 \mu \mathrm{L}$ of Mastermix (Yekta Tajhiz, Iran), $3 \mu \mathrm{L}$ of deionized distilled water, $1 \mu \mathrm{L}$ of each forward and reverse primer, and $2 \mu \mathrm{L}$ of template DNA. PCR program included initial denaturation at $94^{\circ} \mathrm{C}$ for $5 \mathrm{~min}, 35$ thermal cycles including degreasing at $94^{\circ} \mathrm{C}$ for $20 \mathrm{sec}$, primer binding at $60^{\circ} \mathrm{C}$ for $30 \mathrm{sec}$, amplification at $45^{\circ} \mathrm{C}$ for $72 \mathrm{sec}$ and the final amplification at $72^{\circ} \mathrm{C}$ for $2 \mathrm{~min}$.

Amplified DNA was sent to Macrogen Korea Company for sequencing, and the identified sequences were blasted for gene analysis.

\section{Phenotypic Study of Efflux Pump Using Ethidium Bromide-Agar Cartwheel Method}

In order to evaluate the phenotypic activity of efflux pumps, the isolates of $M$. catarrhalis were examined by Ethidium Bromide-agar Cartwheel method. First, ethidium bromide solution (Merck, Germany) was prepared in distilled water at a concentration of 50 $\mathrm{mg} / \mathrm{mL}$ and stored at $4^{\circ} \mathrm{C}$. Plates containing nutrient agar growth medium (Merck, Germany) were prepared with ethidium bromide concentrations from 0 to $2 \mathrm{mg} / \mathrm{L}$. Strains were then cultured on nutrient agar plates containing different concentrations of ethidium bromide from the center of the medium to the side of the medium as a line. Concentrations depended on the type of bacteria and can be variable. The plates were incubated for $24 \mathrm{~h}$ at $37^{\circ} \mathrm{C}$. Fluorescence of each isolate was measured with $\mathrm{Gel}$ Documentation (Hidolgh-Germany) to determine the lowest concentration of ethidium bromide affecting the bacteria $(14,15)$.

\section{Phenotypic Evaluation of Efflux Pump Using Phenylalanine-arginine $\beta$-naphthylamide (Efflux Pump Inhibitor)}

Phenylalanine-arginine $\beta$-naphthylamide dihydrochloride (Phe-Argß-naphthylamide dihydrochloride) was used to evaluate the phenotypic presence of efflux pump. First, two series of Mueller-Hinton agar growth medium (Merck-Elman) were prepared, the first series without inhibitory solution and the second series containing efflux pump inhibition solution. In MuellerHinton agar growth medium containing inhibitor, to dilute $0.25 \mathrm{mg}$ phenylalanine $\beta$-naphthylamide dihydrochloride powder, $0.05 \mathrm{mg}$ of this substance was dissolved in $30 \mathrm{~mL}$ of sterile distilled water and then $1 \mathrm{~mL}$ of this solution was transferred to empty sterile plates. Mueller-Hinton agar was then added to the plates (11) and multidrug-resistant $M$. catarrhalis isolates were cultured. Then standard discs, penicillin, ampicillin, amikacin, gentamicin, tetracycline, chloramphenicol, cefazolin, ceftazidime, trimethoprim-sulfamethoxazole, and ciprofloxacin disks were placed on the medium at standard intervals. The cultures were incubated at $37^{\circ} \mathrm{C}$ for $24 \mathrm{~h}$ and then the inhibited growth area was measured using a millimeter ruler. Measurements were classified as susceptible, resistant, semi-susceptible according to CLSI defined standards (13). The diameter of the inhibition zone was measured in two groups of plates containing phenylalanine-arginine $\beta$ naphthylamide and without phenylalanine-arginine $\beta$ naphthylamide. Increased diameter of the inhibition zone in the presence of the inhibitor indicates the effect of the efflux pump on antibiotic resistance. The results were analyzed using WHONET 5.6 software (WHO, Geneva Switzerland).

\section{Frequency of Efflux Pump acrAB-oprM Gene in Multidrug-Resistant Isolates of $\boldsymbol{M}$. Catarrhalis}

PCR with specific primers was used to identify the efflux pump gene in multidrug-resistant isolates. Primers of efflux pump $M$. catarrhalis efflux pump genes were designed using the genes in NCBI and bioinformatics methods (Table 1 ). 
1061bp

$719 \mathrm{bp}$
F: 5' TTGGTTTAGAAGGCGGTGGC3'

R: 5' TAGTATGGTGCAGGCAGGAC3' acra

$a c r b$
At this point, Mastermix of Yekta Tajhiz (Iran) was used. The PCR mixture consisted of $18 \mu \mathrm{L}$ of Mastermix, $1 \mu \mathrm{L}$ of each of the forward and reverse primers, $2 \mu \mathrm{L}$ of template DNA, and $3 \mu \mathrm{L}$ of double distilled water with a total volume of $25 \mu \mathrm{L}$. The desired Mastermix was mixed with the primers of the efflux pump and the tubes containing the PCR mixture in a thermocycler (Sangavar-Bio-Rad) with a temperature program of 15 sec was initially denatured at $95^{\circ} \mathrm{C}$ and then 35 cycles including denaturing at $94^{\circ} \mathrm{C}$ for $5 \mathrm{sec}$, connection at $58^{\circ} \mathrm{C}$ for $15 \mathrm{sec}$, elongation at $72^{\circ} \mathrm{C}$ for $30 \mathrm{sec}$, and finally final elongation at $72^{\circ} \mathrm{C}$ for $120 \mathrm{sec}$ were done. PCR products were then transferred to $2 \%$ agarose gel and identified by Gel Documentation electrophoresis (Hidolgh, Germany).

\section{Data Analysis and Statistical Analysis}

Data were evaluated using WHONET 5.6 software (WHO, Geneva Switzerland) according to CLSI (2016 version) and SPSS version 22 (SPSS Inc., Chicago, IL., USA). Chi-square test (chi-square) was used to analyze the relationship between the presence of efflux pump genes and drug resistance and an independent t-test was used to analyze the relationship between antibiotics and dependence on the efflux pump before and after using the pump inhibitor. 95\% confidence level was considered for the significance of the tests $(P \leq 0.05)$.

\section{Results}

After performing standard microbiological and biochemical tests, out of 137 randomly collected samples, including 80 men and 57 women aged 3-75 years, 10 isolates were identified as $M$. catarrhalis. The frequency of $M$. catarrhalis isolates by age and sex is shown in Table 2.

Table 2. Frequency of Moraxella catarrhalis isolates by age and sex.

\begin{tabular}{rccccc} 
Sample & Age & Sex & Sample & Age & Sex \\
\hline$N_{1}$ & 65 & Male & $N_{6}$ & 3 & Male \\
$N_{2}$ & 72 & Male & $N_{7}$ & 72 & Male \\
$N_{3}$ & 69 & Male & $N_{8}$ & 75 & Male \\
$N_{4}$ & 5 & Female & $N_{9}$ & 45 & Female \\
$N_{5}$ & 66 & Male & $N_{10}$ & 68 & Male \\
\hline
\end{tabular}

Frequency of $M$. catarrhalis isolates divided by clinical samples, 3 cases of sputum in patients with lower respiratory tract infection (30\%), 1 case of smoker sputum with chronic bronchitis (10\%), 2 cases of sputum in people with suspected tuberculosis (20\%), as well as 2 cases of the adult hypopharynx and oropharynx swabs with sinusitis infection (20\%) and 2 cases of purulent middle ear swabs in children (20\%) were reported.

\section{Results of Antibiotic Resistance by Disk Diffusion Method}

According to the 2016 CLSI standard, out of 10 bacteria isolated from clinical samples, 7 isolates (70\%) had the highest antibiotic resistance to the penicillin, ampicillin, amikacin, gentamicin, chloramphenicol, tetracycline, ciprofloxacin, cefazolin, ceftazidime and lower resistance to trimethoprim/sulfamethoxazole which showed to be resistant to more than two classes of antibiotics and were selected as MDR strains. All strains of bacteria were susceptible to amoxicillin/clavulanic acid (coamoxiclav), azithromycin and erythromycin, and clarithromycin (100\%). It was also found that none of the strains of $M$. catarrhalis are resistant to all antibiotics and the amoxicillin/clavulanic acid, clarithromycin, erythromycin, azithromycin antibiotics can be effective with $100 \%$ susceptibility.

\section{Identification Results of Moraxella catarrhalis Isolated by PCR Test}

After measuring the diameter of the inhibition zone, 7 isolates resistant to more than two classes of antibiotics were selected to perform the rest of the 
steps of this study. Using SrRNA16 specific primer, the isolates resistant to several drugs were identified. The formation of a band of 1360 pairs showed the presence of $M$. catarrhalis (Figure 1).

Phenotypic Results of the Presence of Efflux Pump Using Ethidium Bromide and Cartwheel Method

To identify the efflux pump activity of $M$. catarrhal isolates, all isolates in the study were cultured with ethidium bromide agar technique and Cartwheel method. The results showed that 7 isolates $(70 \%)$ had an efflux pump (also to ensure the presence of the Influx pump, all 10 isolates were evaluated). As shown in Figure 2, after being placed under a Gel Documentation device, 7 isolates of $M$. catarrhalis were unable to store these dyes in the cell.

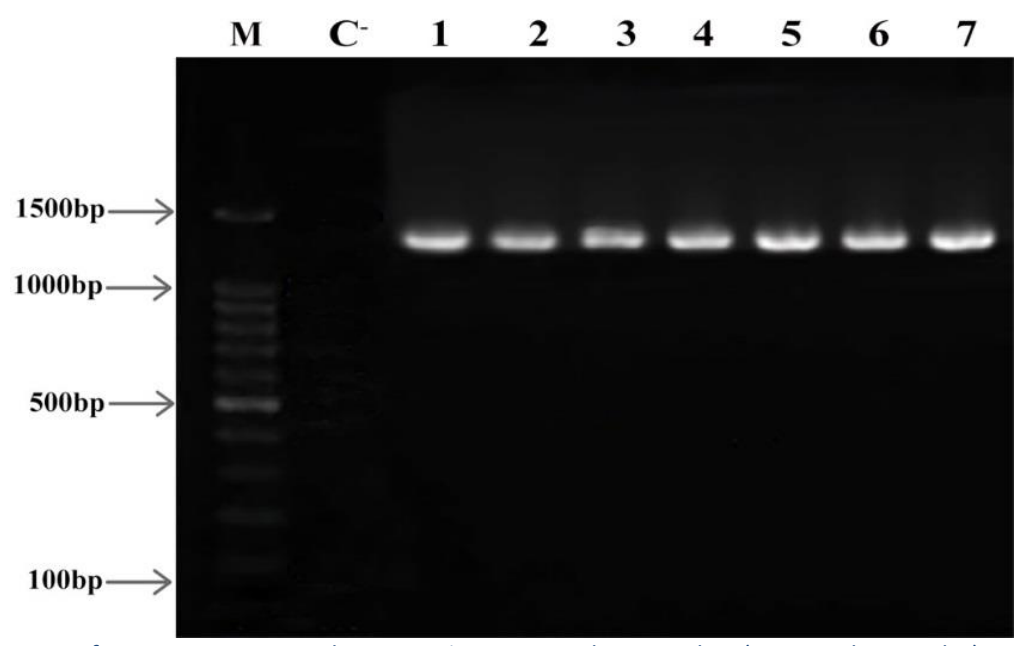

Figure 1. Electrophoresis of 16SrRNA gene product on 2\% agarose gel M: Marker (Gene Ruler 100 bp) C: Negative Control 1-7 columns: multidrug-resistant isolates Product Length: $1360 \mathrm{bp}$

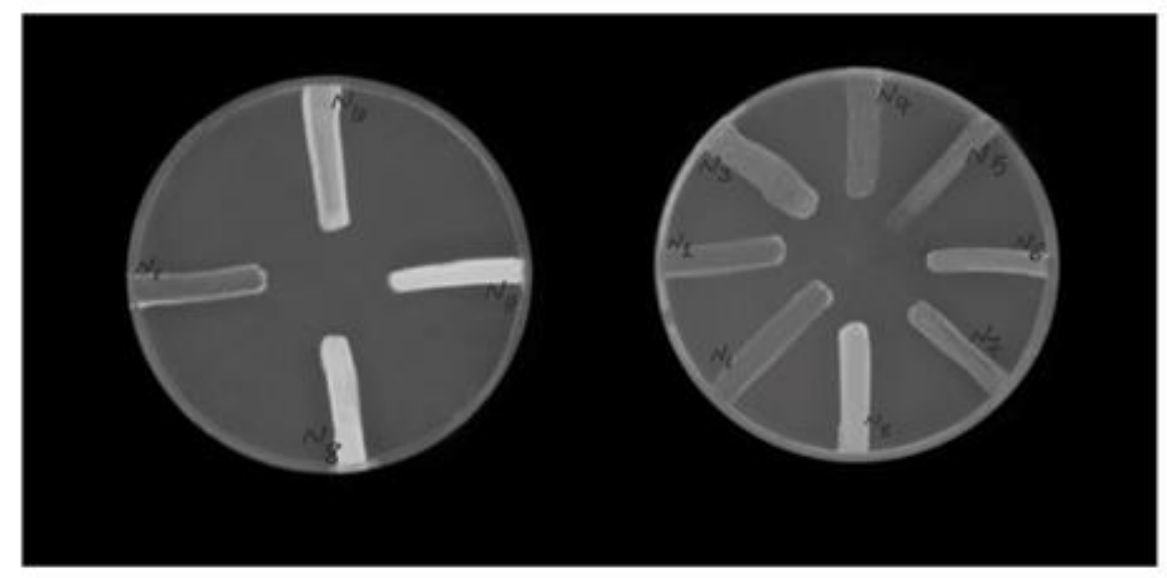

(B)

(A)

Figure 2. Results of phenotypic analysis of efflux pump. Each line is indicative of a Moraxella catarrhalis isolate. Hyaline lines are indicative of efflux pump inactivation and opalline lines are indicative of efflux pump activation. A: Fluorescence plate including $0.5 \mathrm{~g} / \mathrm{mL}$ ethidium bromide and B: Fluorescence plate including $1 \mathrm{~g} / \mathrm{mL}$ ethidium bromide

\section{Results of the Dependence of Antibiotic Resistance} on Efflux Pump Activity Using Efflux Pump Inhibitor

After the addition of the efflux pump inhibitor to the growth medium, cefazolin, ceftazidime, ciprofloxacin, chloramphenicol, tetracycline antibiotics became more antibacterial (Figure 3). These antibiotic resistance of $M$. catarrhalis isolates were dependent on the efflux pump because their growth inhibition zone changed compared to the first antibiogram (absence of inhibitor) and the diameter of the inhibition zone increased in the presence of inhibitor. Therefore, this issue shows the effect of the efflux pump on antibiotic resistance. 


\section{Results of Frequency Study of acra, acrb, oprm Genes}

After amplification of acra, acrb, and oprm genes for all multidrug-resistant $M$. catarrhalis isolates, PCR products were observed in bands according to Figures 4,5 and 6 on $2 \%$ agarose gel. The efflux pump genes were present in all 7 multidrug-resistant isolates (Figures 4, 5, 6).

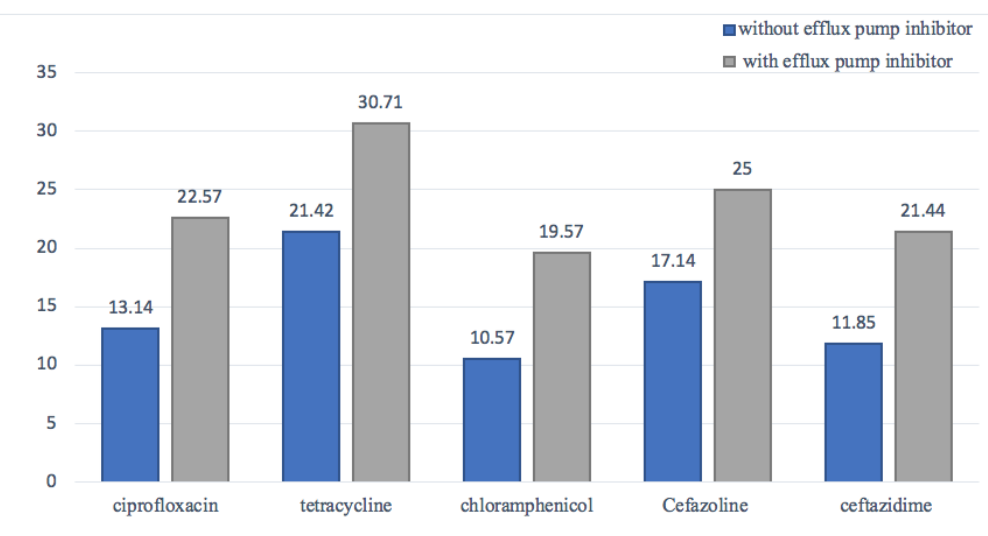

Figure 3. Comparing Moraxella catarrhalis isolates resistance patterns to ciprofloxacin, tetracycline, chloramphenicol, cefazoline, and ceftazidime with and without efflux pump inhibitor presence.

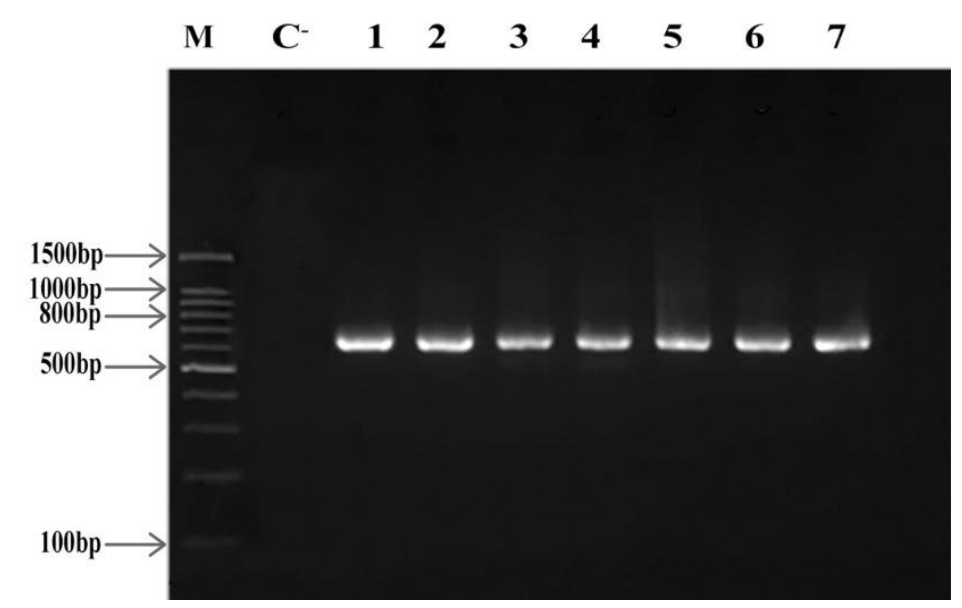

Figure 4. oprm electrophoresis on 2\% agarose gel, M: Marker (Gene Ruler 100 bp), C:: Negative Control, 1-7 columns: multidrug-resistant isolates, Product Length: $692 \mathrm{bp}$

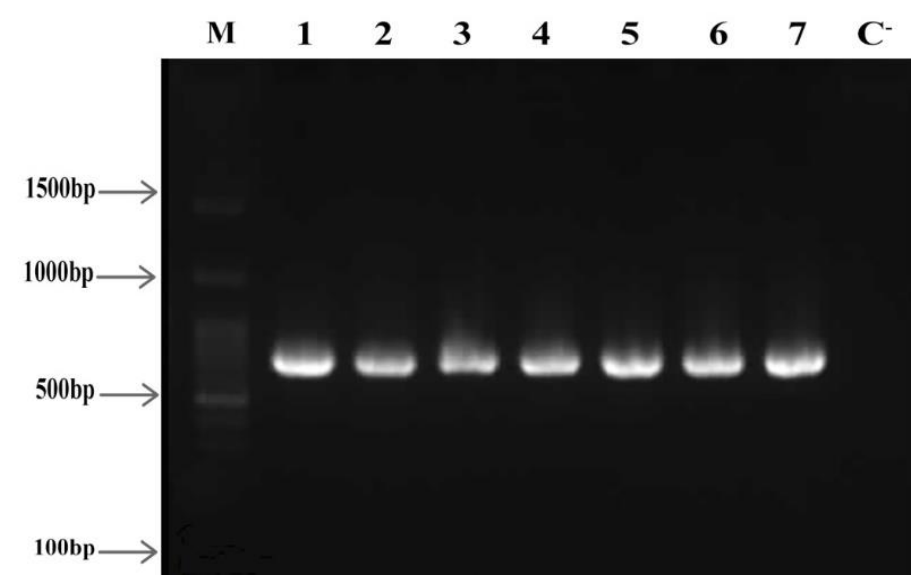

Figure 5. acrb electrophoresis on 2\% agarose gel, M: Marker (Gene Ruler 100 bp), C: Negative Control, 1-7 columns: multidrug-resistant isolates, Product Length: $719 \mathrm{bp}$ 


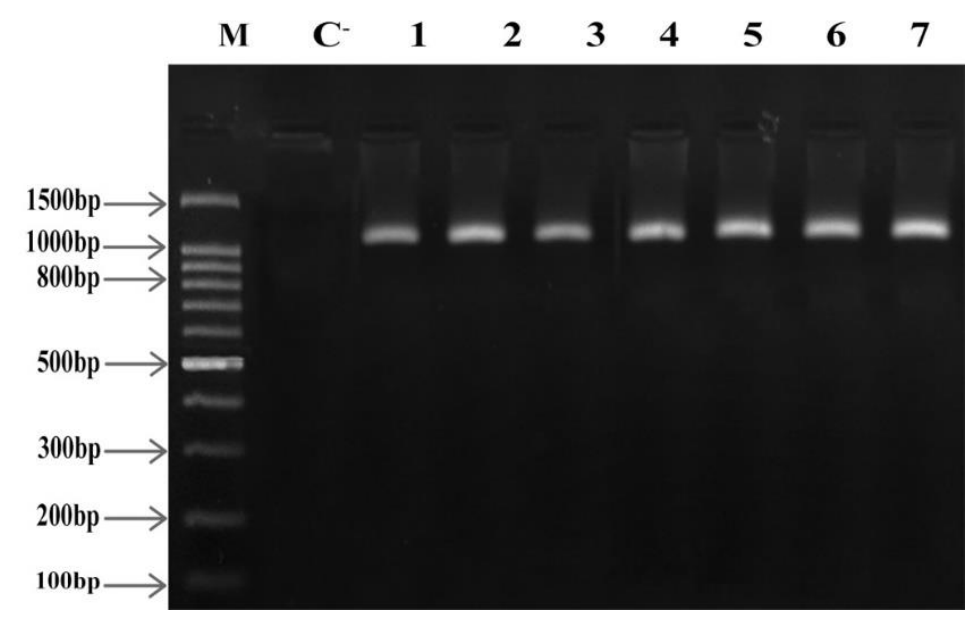

Figure 6. acra electrophoresis on 2\% agarose gel, M: Marker (Gene Ruler 100 bp), C : Negative Control, 1-7 columns: multidrug-resistant isolates, Product Length: $1061 \mathrm{bp}$

Also, according to the Chi-square test, a significant relationship was observed at the level of $\mathrm{P}$-value $\leq 0.05$ between antibiotic-resistant isolates and the presence of acla, acrb and oprm genes in the efflux pump and no significant relationship was observed at the level of $P$-value $\leq 0.05$ for the four co-amoxiclav, erythromycin, azithromycin, and clarithromycin antibiotics, which were reported to be susceptible in all isolates.

\section{Discussion}

Moraxella catarrhalis has been reported in recent years as an important factor in lower and upper respiratory infections and it is the most common type that can be isolated from sputum, middle ear secretions, sinuses, and throat and mouth swabs (5). In this study, a total of 10 cases of $M$. catarrhalis were isolated from 137 different clinical samples. In a study conducted by Ghaznavi et al. (2005) on 200 patients, 17 samples of M. catarrhalis were isolated (16). A 2016 study by Sillanapau et al. on 222 specimens isolated 22 cases of $M$. catarrhalis (17). In a Miravitlles study of 48 patients with chronic obstructive pulmonary disease, eight $M$. catarrhalis patients (9\%) isolated as the main cause of the disease (18). The mentioned values are somewhat consistent with the number of bacteria isolated in this study (10 samples). However, the small difference observed may be due to the different prevalence of bacteria in different geographical areas.

The results of antibiotic susceptibility showed that the highest resistance was related to gentamicin, amikacin, penicillin $\mathrm{G}$, ampicillin, ceftazidime, cefazolin, tetracycline, chloramphenicol, and ciprofloxacin (70\%). Isolates of this study showed moderate resistance to trimethoprim-sulfame-thoxazole antibiotics. Also, the isolated strains were completely susceptible to azithromycin, erythromycin, clarithromycin, and amoxicillin/ clavulanic acid antibiotics (100\%).

Various studies have been performed to evaluate the antibiotic resistance of $M$. catarrhalis strains. In 2006, Naderi et al. isolated 54 samples of $M$. catarrhalis from 1161 children and examined the pattern of antibiotic resistance, with the highest susceptibility to amoxicillin/clavulanic acid (100\%) and the highest resistance to penicillin (100\%) (19). A 2014 study by Bandet et al. showed that all strains of isolated $M$. catarrhalis were highly susceptible to amoxicillin/clavulanic acid, erythromycin, and clarithromycin antibiotics (20). These results are consistent with the findings of the present study, which were $100 \%$ susceptible to amoxicillin/clavulanic acid and macrolides. Also, in a similar study conducted by Abdullah et al. in 2013 on 766 patients, 39 strains of $M$. catarrhalis were isolated, with the highest resistance to amikacin (92.3\%) and the highest susceptibility to amoxicillin/clavulanic acid (100\%). A study by Ramadan et al. in 2012 examined 200 patients, of whom $91.3 \%$ were resistant to penicillin and $100 \%$ susceptible to amoxicillin/clavulanic acid, ciprofloxacin, erythromycin, gentamicin, and $97.7 \%$ to tetracycline (22).

From the comparison of the present study and other studies published in the field of the prevalence of antibiotic-resistant strains of $M$. catarrhalis bacteria, it is clear that antibiotics such as penicillin, ampicillin, ceftazidime, cefazolin, chloramphenicol, tetracycline, ciprofloxacin, gentamicin, amikacin can no longer be used as a drug against $M$. catarrhalis due to repeated reports of resistance. One of the reasons for the 
increase in resistance in recent years is the excessive use of antibiotics, geographical and cultural factors such as the arbitrary use of antibiotics, and the availability of antibiotics, each of which has a role to play in increasing antibiotic resistance (23).

The AcrAB-OprM multidrug leakage system is the first pump under study in $M$. catarrhalis, which is a homolog of the efflux pump in Escherichia coli $(5,24)$. The number of studies performed on the efflux pump genes in $M$. catarrhalis is relatively limited and there are not many studies in this field. According to the results obtained in this study with phenotypic and genotypic tests, the presence of this pump and its involvement in antibiotic resistance were declared. The strength of this study was the phenotypic study at the same time as the genotypic study of the efflux pump activity, because despite the fact that the genotypic method is more accurate and reliable, simultaneous phenotypic and genotypic methods show more reliable results. One of the advantages of the phenotypic method is the faster cultivation and less expensive identification of the efflux pump (14, 15).

Also, the Cartwheel method, in addition to determining the phenotypic activity of the efflux pump, which shows the MDR phenotype in clinical isolates of gram-positive and gram-negative pathogenic bacteria; provides a rapid comparison of the activity of efflux resulting from isogenic mutations in the laboratory caused by continuous irradiation, deletion of a gene or group of genes, or growth of a bacterial strain under different conditions (temperature, $\mathrm{pH}$, etc.) (14).

Based on the evidence, the activity of the efflux pump systems in $M$. catarrhalis was not previously fully identified. According to recent studies and PCR results of isolated strains in this study, it is shown that there are a number of efflux pumps in the $M$. catarrhalis bacteria and due to the increased resistance of $M$. catarrhalis and the increase in respiratory diseases, the study of these genes can be important in examining the treatment pattern of infectious and respiratory patients $(5,24)$. Using sequencing data for the $\mathrm{BBH} 18$ strain of $M$. catarrhalis in 2015, Spaniol et al. showed that Acr and Mtr efflux pumps were present. Also, following the previous studies, the authors (in 2010) showed that after treatment with amoxicillin, purine M35 is negatively regulated, which leads to increased resistance. These cascading reactions represent a new mechanism of resistance to aminopenicillins in $M$. catarrhalis. The role of AcrAB-OprM efflux pump in antibiotic resistance was also identified in that study by constructing mutant strains containing $a c r A$, acrB, and oprM genes in M. catarrhalis O33E (5).
The phenylalanine-arginine- $\beta$-naphthylamide dihydrochloride inhibitor is one of the first inhibitors of RND pumps in gram-negative bacteria $(26,27)$. Studies show that by disrupting efflux pumps in resistant strains of bacteria with the help of efflux inhibitors, the properties of antibiotics and biocides are significantly increased (28). In a 2015 study by Gholami et al., examining 60 species of Acinetobacter baumannii, it was shown that susceptibility to imipenem increased in the presence of a phenylalanine-arginine- $\beta$-naphthylamide

dihydrochloride inhibitor. So that for $96.6 \%$ of the isolates, the minimum inhibitory concentration decreased from 4 to $64 \mathrm{\mu g} / \mathrm{mL}$ (29). In 2013, Dal et al. examined the effect of PAßN and NMP inhibitors on the ade $B$ gene in 40 Acinetobacter isolates. The antimicrobial properties of some antibiotics along with the efflux inhibitor increased significantly, but no significant change was reported in aminoglycosides (30). In 2010, Hornsey et al. showed a significant relationship in Acinetobacter between the expression of the efflux pump and the MIC (31). In a 2012 study by Mavri and Mozin, researchers found that disrupting efflux pumps in resistant strains of Campylobacter jejuni and Escherichia coli by efflux pump inhibitors increased the antimicrobial properties of antibiotics and biocides. The inhibitory effect of alpha naphthylamine was also investigated (32). The results of the above studies are consistent with the present study and show the importance of inhibiting the efflux pump.

In another 2012 study, Sonnet et al. showed that the phenylalanine inhibitor beta-naphthylamide and antibiotics such as ciprofloxacin in Pseudomonas aeruginosa were effective in suppressing resistance. For the clinical use of high-efficiency efflux pump inhibitor, a combination of inhibitors was prepared and their effect on different pumps was investigated (26). In the present study, it was shown that the efflux pump can be involved in reducing resistance to fluoroquinolones and some beta-lactams, tetracyclines, and chloramphenicol; Because by inactivating the pump, the effect of these antibiotics on all isolates increased. Therefore, the use of an efflux pump is an issue that can be considered to reduce the emergence of antibiotic-resistant species. There have been very few studies on the antibiotic resistance associated with the efflux pump and its inhibitor in the $M$. catarrhalis bacteria, but the results of this study were consistent with other bacteria. Given the increase in bacterial resistance and the significant role of efflux pumps in these resistances, the need to discover new antibiotics and inhibitor pump inhibitors seem obvious (33). Although antibiotic resistance may not completely restore susceptibility to multidrug-resistant organisms only by inhibiting efflux pumps, given the maximal activity of 
the efflux pump in $70 \%$ of the strains of this study, the association between the expression of efflux pumps and antibiotic resistance should not be overlooked. Genetic studies of these pumps and other involved factors including beta-lactamase enzymes will be considered necessary in future studies.

\section{Conclusion}

According to the approval of phenotypic and genotypic role of efflux pumps and dependence of antibiotic resistance to efflux pump activity using pump inhibitors, research and novel drugs can be developed in order to control and treat Moraxella catarrhalis infections. Development of efflux pump inhibitors can revive antibiotic efficacy. On the other hand, new proposals can be practiced to inhibit efflux pumps in order to decrease drug resistance in $M$. catarrhalis.

\section{Acknowledgement}

I would like to express my gratitude and thanks to all those who helped me during the implementation of this research. It is worth mentioning that this article is the result of a part of the master's thesis of Ms. Parvin Mohammad Shafiei from the Islamic Azad University, Kazerun Branch.

\section{Conflict of Interest}

The authors declared no conflict of Interest.

\section{Financial Resources}

This article was financially supported by the authors. 


$$
\begin{aligned}
& \text { مجله ميكروبشناسى يزشكى ايران }
\end{aligned}
$$

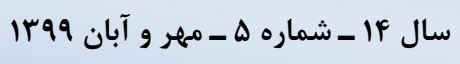

$$
\begin{aligned}
& \text { Journal homepage: www.ijmm.ir }
\end{aligned}
$$

\title{
بررسى شيوع مقاومت آنتىبيوتيكى و ارزيابى فنوتيِي و زنوتيِي يمٍ افلاكس AcrAB-OprM در جدايههاى كلينيكى مقاوم به جند دارو در باكترى موراكسلا كاتاراليس در شهرستان كازرون، ايران
}

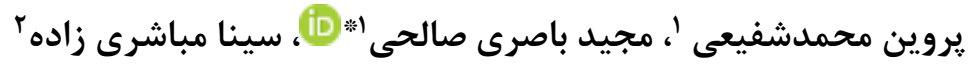

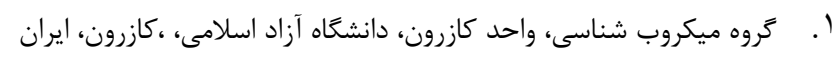

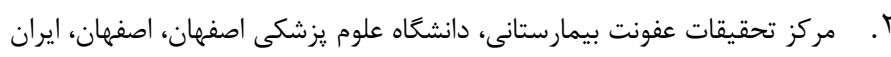

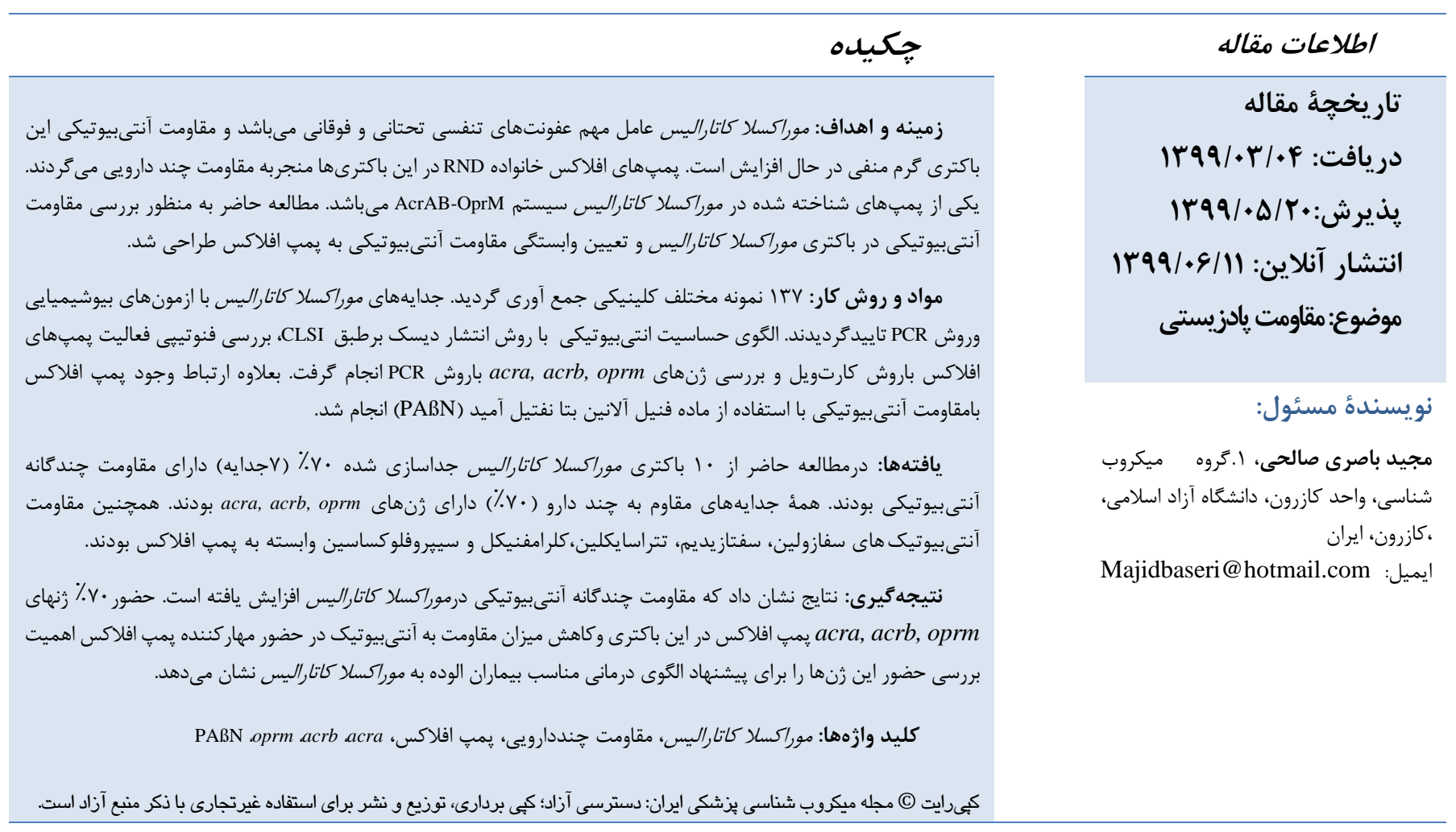

مقدمه

تنفسى تحتانى (برونشيت حاد و ينومونى در بالغين) را ايجاد نمايد (1-1). موراكسلا كاتاراليس بعد از استريتوكوكوس بِّومونيه و هموفيلوس آنفلونزا، به عنوان عامل باكتريايى عفونت، مطرح است

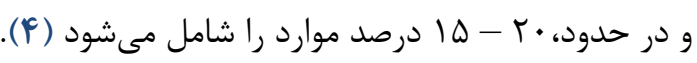

درمان جنين عفونتهاى تنفسى به دليل مقاومت گسترده

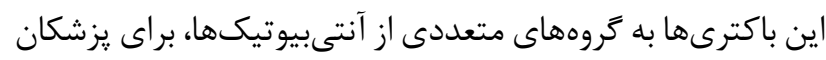

موراكسلا كاتاراليس (Moraxella catarrhalis) ديِلوكوك كرم منفى غيرمتحرك و بدون ريخمان است كه تا ه99 19 بهعنوان فلور نرمال سيستم تنفسى، باكترى غير بيمارىزا در نظر گرفته

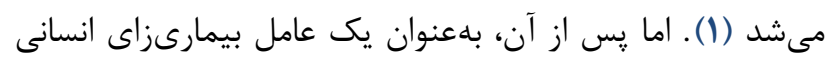

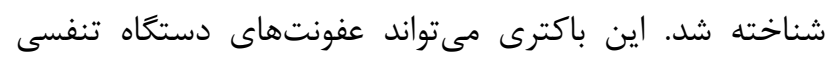

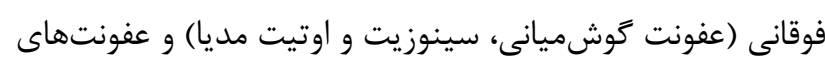


مصنوعى روى باكترىهاى گرم مثبت و منفى آزمايش شده است

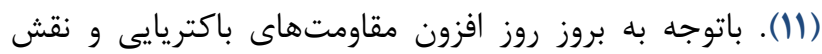

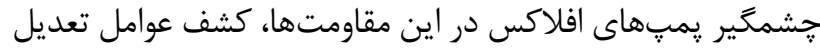
كننده مقاومت و به طور اختصاصىتر، مهاركنندههاى يمب افلاكس،EPIs) Efflux pump inhibitors) از اهميت بهسزايى برخوردار هستند. بنابراين طراحى داروهاى نوين مستلزم شناسايى و درك وضعيت سيستمهاى ايجاد كننده مقاومت ازجمله يمب

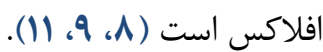

با افزايش مقاومت باكترىها به آنتىبيوتيكهاى متعدد خطر افزايش بيمارىهاى عفونى و تنفسى سلامت بشر را تهديد

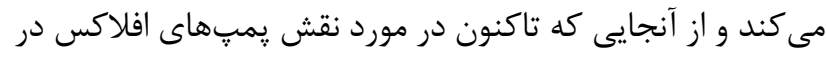

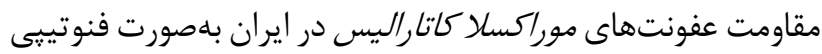

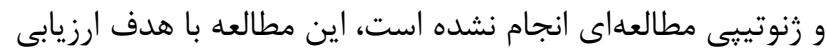
شيوع فنوتييى و زنوتييى زنهاى acrAB-oprM مرتبط با

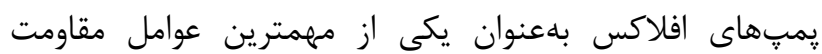
آنتىبيوتيكى در باكترى موراكسلا كاتاراليس و مهار آن با استفاده از فنيل آرزينين بتا نفتيل آميد (PaßN) بهمنظور ارائه به مراكز خدمات درمانى انجام گرفت.

\section{مواد و روشا}

\section{نمونه}

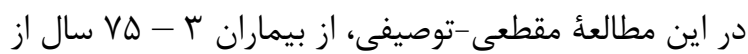

هر دو جنس مرد و زن مبتلا به عفونتهاى تنفسى و ينومونى

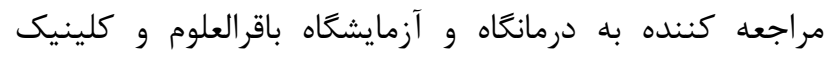

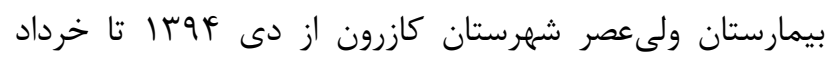
هوبا نمونه مطالعه، افراد مراجعه كنندهٔ مشكوك به سل، نمونههاى مبتلايان

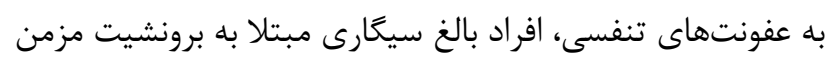

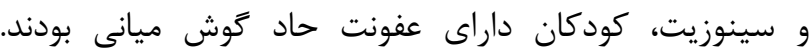
تشخيص موارد فوق توسط يزشك متخصص انجام شد.

در نهايت ITV حنجرهاى) و ترشحات جركى گوش ميانى گرفته شده در شرايط استاندارد به آزمايشگاه منتقل شد. نمونهها در آزمايشگاه بر روى محيط ريط

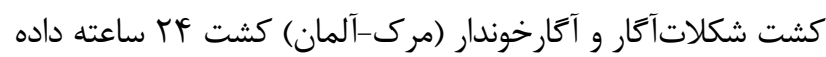
شدند. سيس با استفاده از تستهاى ميكروبشناسى و بيوشيميايى

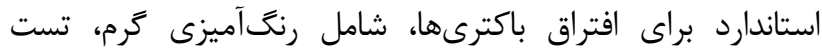
اكسيداز، كاتالاز، DNase، تست تخمير قند (كلوكز، سوكروز، مالتوز،
بسيار مشكل است (ب). بخشى از اين مقاومت، اكتسابى و بخشى ذاتى است. يكى از ويزگى هاى منحصر به فرد اين اركانيسمها

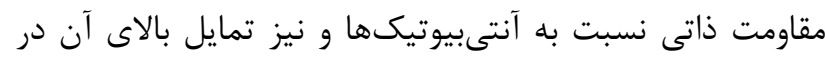
كسب مقاومت آنتىبيوتيكى است (ه). مقاومت به آنتىبيوتيكها مشكلات فراوانى را براى درمان عفونت موراكسلا كاتاراليس ايجاد

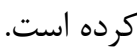

مقاومت ذاتى اين باكترى مىتواند در نتيجه اثر متقابل مهار

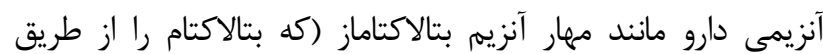
هيدروليز اين حلقه تغيير مىدهد) و ايجاد مقاومت دارويى از طريق تغيير در نفوذيذيرى غشاى سلولى باكترى (مانند يورينها) و بيان سيستمهاى تراوشى فعال يا افلاكس ״ميها، صورت گيرد (ه).

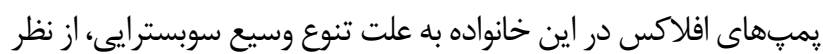
فيلوزنى به ينج خانواده بزرگ تقسيم شدهاند. از بين اين خانوادهها، يميهاى RND (Division Nodulation Resistance) يمٍٍ إِى افلاكس جند دارويى (Multidrug Efflux Pumps) هستند

سيستم افلاكس پمب سه گانه AcrAB-OprM يك سيستم افلاكس از خانواده RND در موراكسلا كاتاراليس است. اين يمٍ شامل، يك پمب غشا داخلى (AcrB)، يك كانال غشا خارجى و يك : يروتئين آدايتور يرى يلاسميك (OprM) منجر به خروج آنتىبيوتيك از ميان هر دو غشا داخلى و خارجيى يُونى

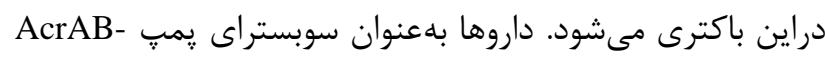
OprM

به نوبه خود، منجر به بروز مقاومت جند دارويى مىشود (ه). يم״هاى افلاكس نه تنها باعث افزايش حداقل غلظت مهاركنند نيروى محركه يروتونى (PMF) و با كاهش غلظت دارو در داخل سلول باعث ايجاد سويههاى مقاوم به دارو مى گردند (^، V). اين

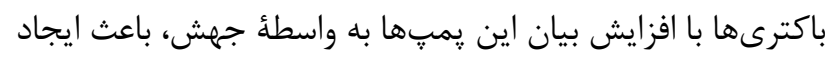

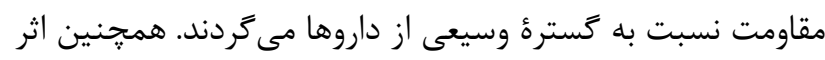
همافزايى آنها با ساير مكانيسمهاى مقاومت دارويى بسيار حائز اهميت بوده و لازم است مانند ساير مكانيسمهاى مقاومت، راهكارهاى مقابله با آنها بررسى گردد (•1-1). بهنظر مىرسد شناخت و مهار پيمٍهاى افلاكس يك راهكار اميدواركننده براى تاثير مواد ضدباكتريايى باشد. درسالهاى اخير بهمنظور رفع مشكل

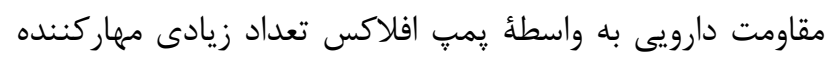
ازجمله محصولات طبيعى، انواع آنتىبيوتيك و مولكولهاى 
تكثير شده براى تعيين توالى به شركت ماكروزن كره فرستاده

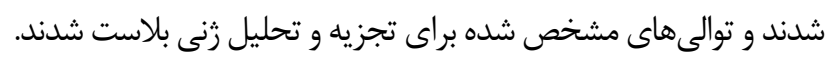
بر رسى فنوتيبى يمٍ افلاكس با استفاده از روش كارت ويل اكَار_ اتيديوم برومايد

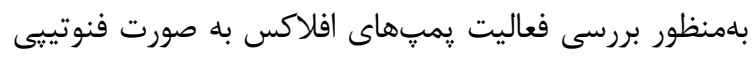

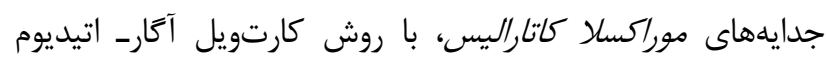

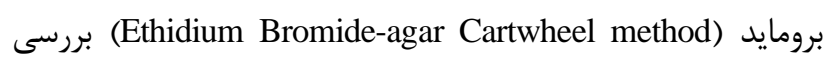
شدند. ابتدا محلول اتيديوم برومايد (شركت مرك، آلمان) در آب مقطر

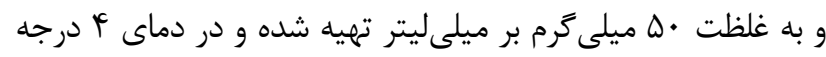

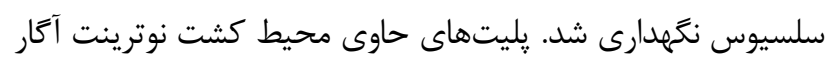

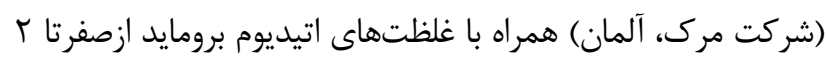

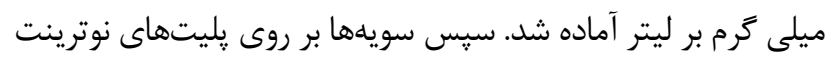

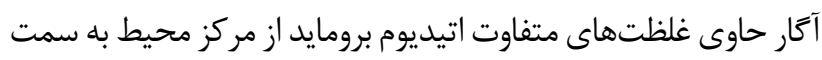

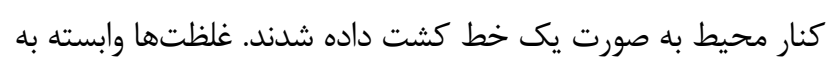

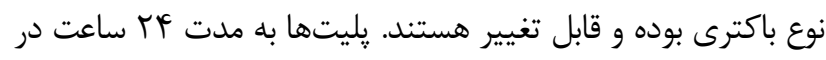

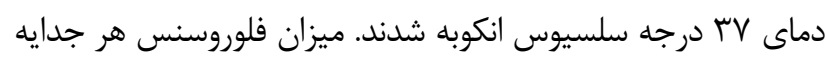

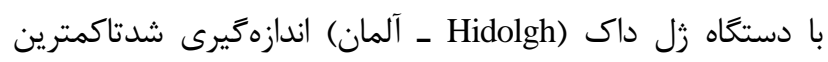

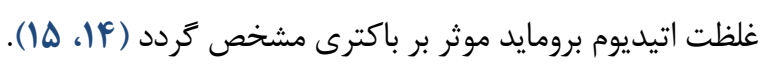
بر رسى فنوتيبى يمب افلاكس با استفاده از ماده فنيل آلانين

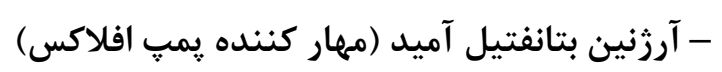

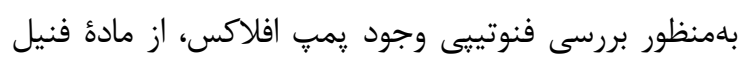

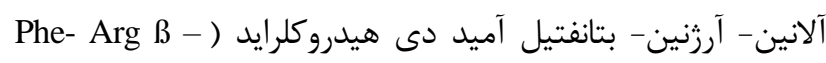
(naphthylamide dihrochloride كشت مولرهينتون آحار (مرك-آلمان) تهيه شد كه سرى اول بدون

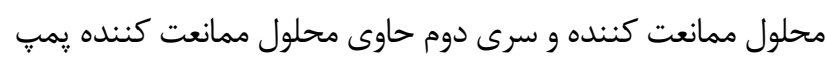

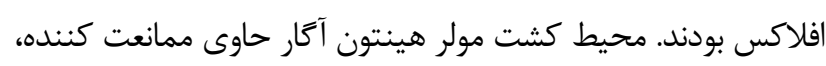

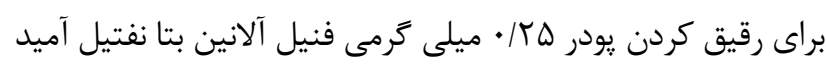

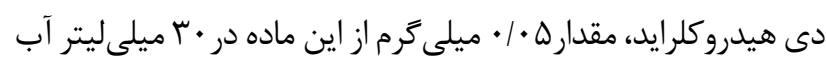

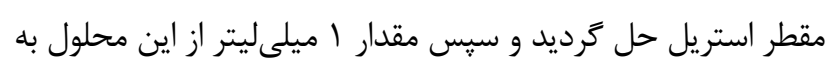

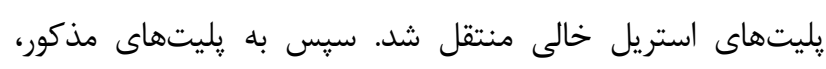

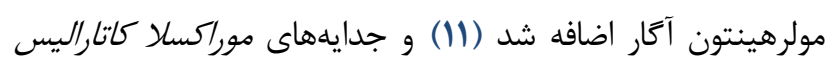

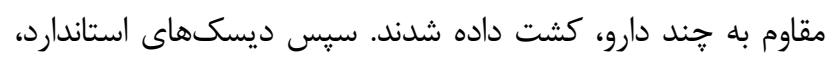

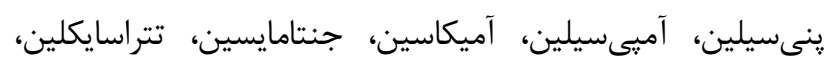

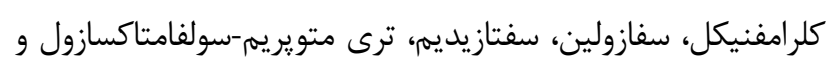

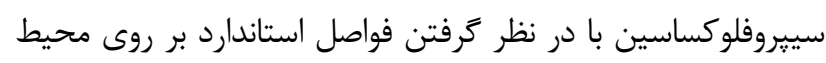

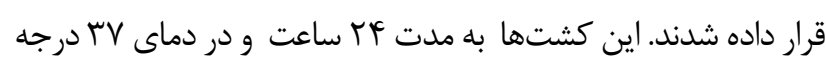

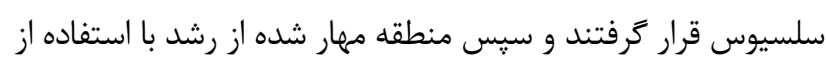

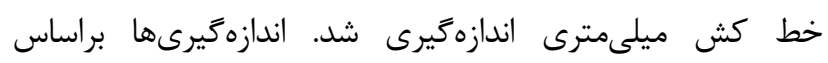

فروكتوز و لاكتوز) و احياى نيترات براى شناسايى و جداسازى باكترى (آنا موراكسلا كاتاراليس استفاده شد (r) (1).

تعيين حساسيت آنتىبيوتيكى با روش Kirby-Bauer

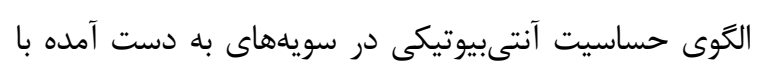

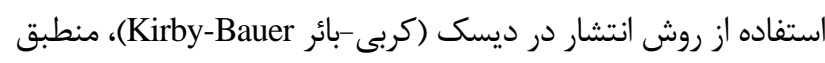

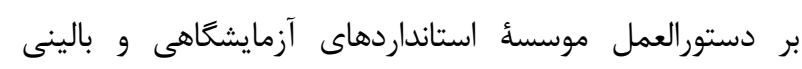
نسخئ (Clinical and Laboratory Standards Institute)CLSI

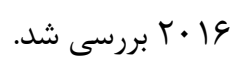

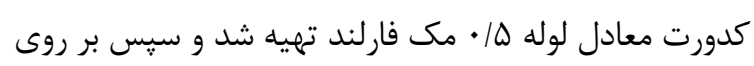
محيط كشت مولرهينتون آكار (مرك، آلمان) كشت ع آن ساعته انجام

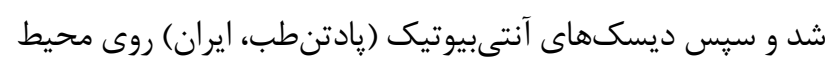

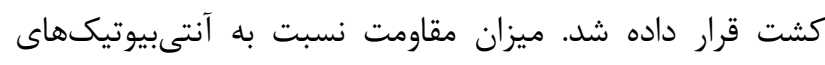

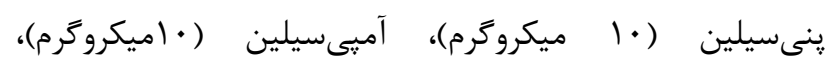

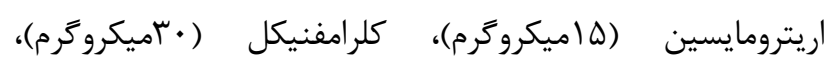

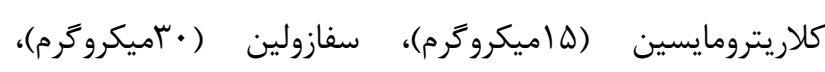

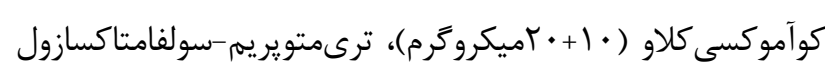

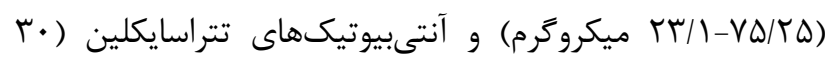

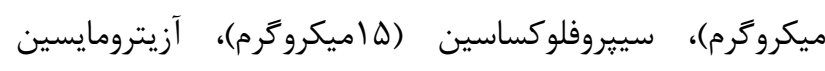
(هاميكرو

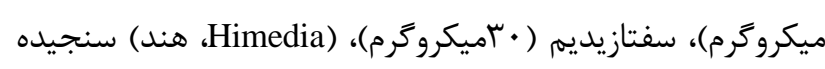

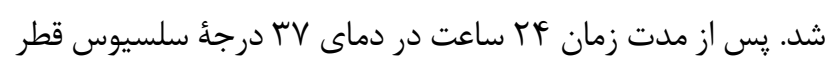

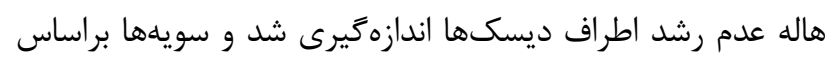
دستورالعمل CLSI دركروههاى حساس، نيمهحساس و و مقاوم

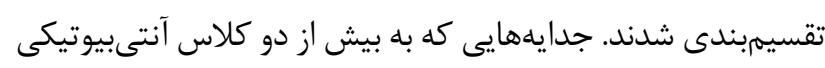

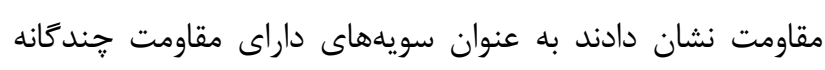

MDR

تشخيص موراكسلا كاتاراليس با PCR

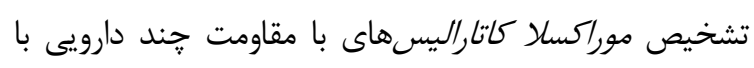

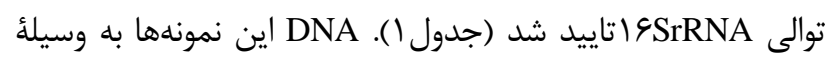

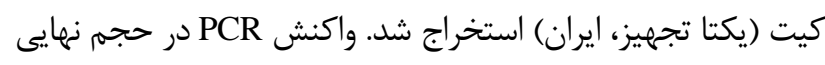

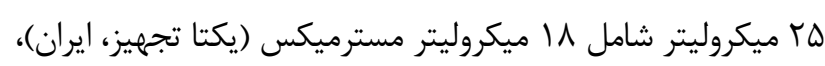

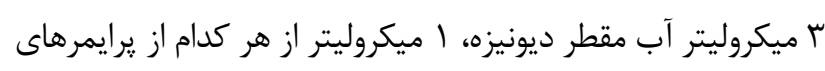

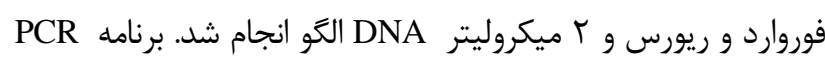

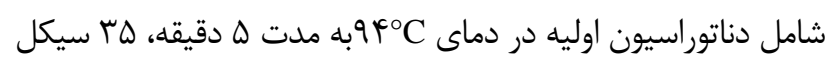
حرارتى شامل واسرشتسازى در دماى يرايمر در دماى

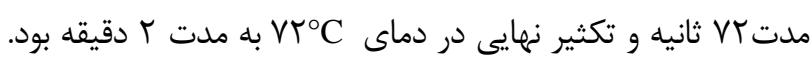


شامل واسرشتسازى، در دماى 9 و درجه سلسيوس به مدت ه ه ثانيه، اتصال در دماى ه ه درجه سلسيوس به مدت دان ها اثانيه، طويل

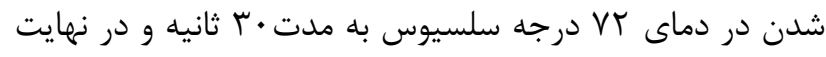

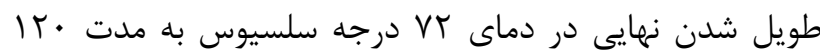

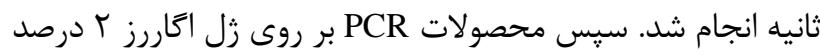
انتقال داده شد و به وسيله دستگاه زل داك (Hidolgh، آلمان)

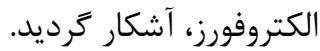

تجزيه تحليل دادهها و آناليز آمارى

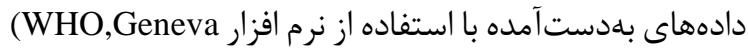
WHONET 5.6 Switzerland)

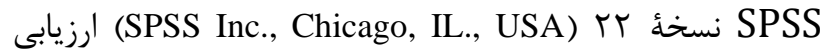
شدند. از آزمون مربع كاى (كاى دو) براى تحليل ارتباط بين وجود

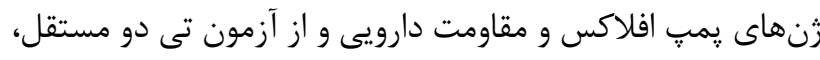

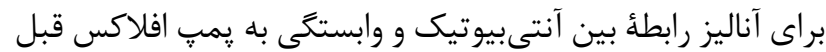

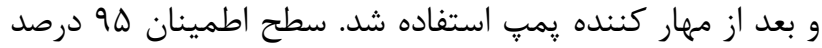

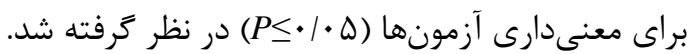

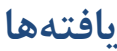

يس از انجام آزمونهاى استاندارد ميكروبيولوزى و بيوشيميايى،

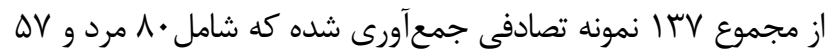

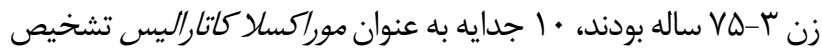

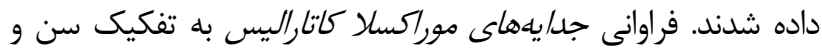
جنس در جدول r نشان داده شده است.
استانداردهاى تعريف شده CLSI بصورت حساس، مقاوم، نيمه حساس

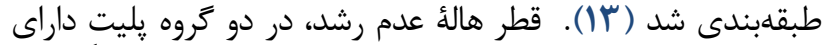

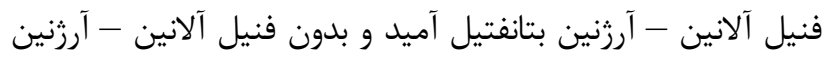
بتانفتيل آميد اندازميرى شد. در صورتيكه قطر هاله بدون رشد در الدين

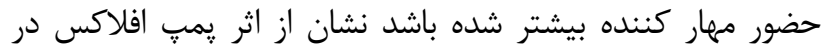

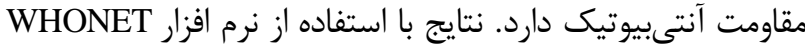
(WHO,Geneva Switzerland) بر رسى فراوانى زن acrAB-oprM يُمٍ افلاكس در جدايههاى مقاوم به جند دارو موراكسلا كاتاراليس از روش PCR با برايمرهاى اختصاصى براى شناسايى زن يمب افلاكس درجد/يههاى مقاوم به جند دارو استفاده شد. يرايمر

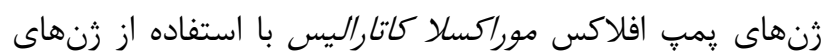
موجود در (NCBI) و با استفاده از روشهاى بيوانفورماتيك طراحى ليى

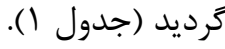
در اين مرحله نيز از مستر ميكس يكتا تجهيز (ايران) استفاده

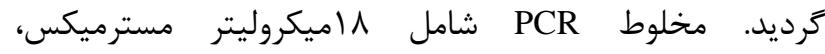

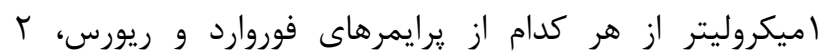

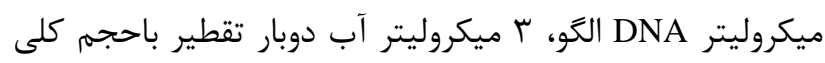

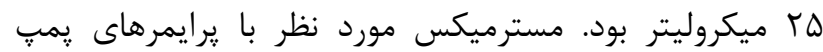
افلاكس مخلوط كرديد و تيوضهاى حاوى مخلوط PCR در دستخاه

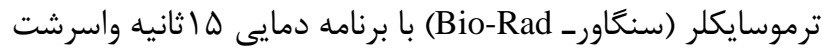

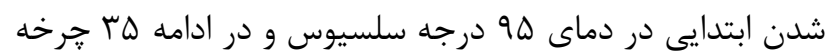

جدول ا. برايمرهاى طراحى شده مورد استفاده درمطالعه

\begin{tabular}{|c|c|c|}
\hline 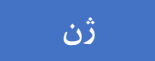 & يرايمر & طول ثن (جفت باز) \\
\hline $16 s \mathrm{rRNA}$ & $\begin{array}{c}\text { F: 5' CAGGCCTAACACATGCAAGTC3' } \\
\text { R: } 5 \text { ' GGGCGGAGTGTACAAGGC3' }\end{array}$ & bpırs. \\
\hline oprm & $\begin{array}{l}\text { F: 5' GCCAGTCAAAAACAGCAAGC3' } \\
\text { R: 5' TAATCCACCAATGCCGACTG3' }\end{array}$ & sqr bp \\
\hline acra & $\begin{array}{l}\text { F: 5' TTGGTTTAGAAGGCGGTGGC3' } \\
\text { R: 5' TAGTATGGTGCAGGCAGGAC3' }\end{array}$ & $1.91 \mathrm{bp}$ \\
\hline$a c r b$ & $\begin{array}{l}\text { F: 5' ACCACAGGTGAGGCAAGTAT3' } \\
\text { R: 5' TGCCGATGGCGTTTGTTAAAT3' }\end{array}$ & $\vee 19 \mathrm{bp}$ \\
\hline
\end{tabular}


جدول r. فراوانى جدايههاى موراكسلا كاتاراليس به تفكيك سن و جنس

\begin{tabular}{|c|c|c|c|c|c|}
\hline جنس & سن & نمونه & جنس & سن & نمونه \\
\hline مرد & $r$ & $\mathrm{~N}_{\varphi}$ & مرد & $9 \Delta$ & $\mathbf{N}_{1}$ \\
\hline مرد & VT & $\mathrm{N}_{\mathrm{v}}$ & مرد & VT & $\mathbf{N}_{r}$ \\
\hline مرد & $V \Delta$ & $\mathrm{N}_{\curlywedge}$ & مرد & 99 & $\mathbf{N}_{\boldsymbol{r}}$ \\
\hline زن & $F D$ & $\mathrm{~N}_{q}$ & زن & $\Delta$ & $\mathbf{N}_{f}$ \\
\hline مرد & $9 \wedge$ & $\mathrm{N}_{1}$ & مرد & 99 & $\mathbf{N}_{\Delta}$ \\
\hline
\end{tabular}

مقاوم به جند دارو تعيين هويت شدند. تشكيل باند • عسا جفت بازى نشان دهنده حضور موراكسلا كاتاراليس بود (شكل ( ).

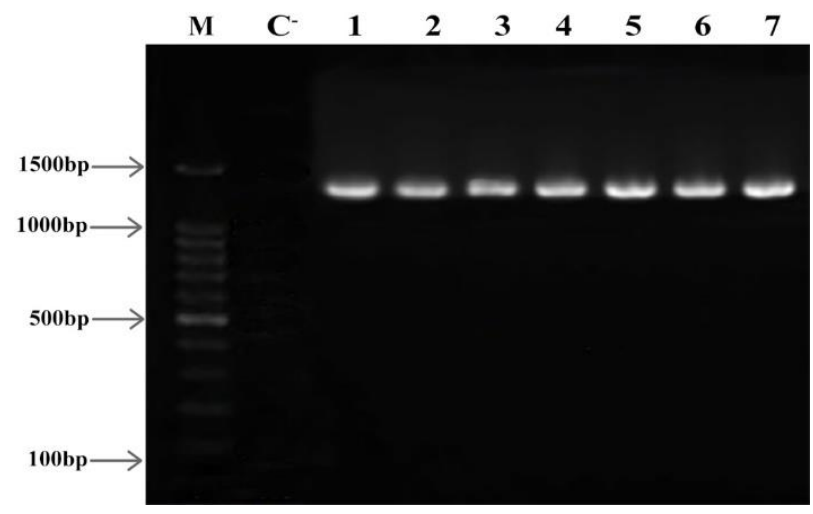

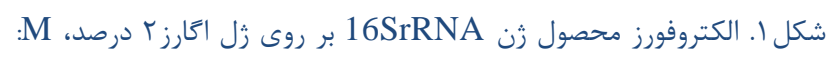

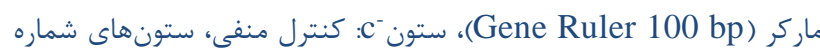

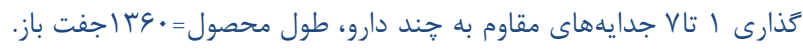

نتايج فنوتيِى وجود يمب افلاكس با استفاده ازاتيديوم برومايد و روش كارتويل

براى تشخيص فعاليت يمٍ افلاكس جدايههاى موراكسلا كاتاراليس، همةٔ جد/يههاى مطالعه با تكنيك اكار حاوى اتيديوم

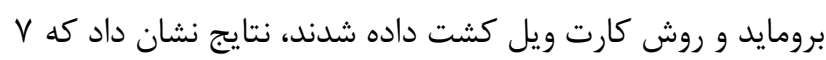

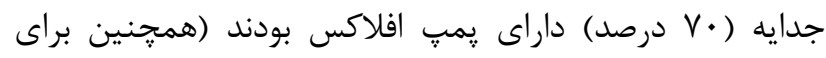

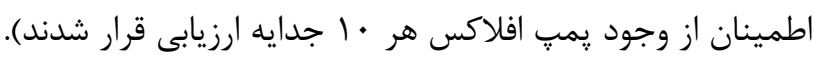

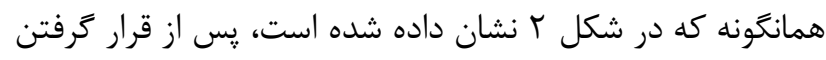

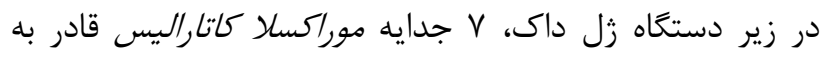
ذخيرهسازى اين رنگها در سلول نبودند. خطوط كشت شفاف بيانگر فعال نبودن پيّ افلاكس و خطوط كشت مات بيانگر فعال

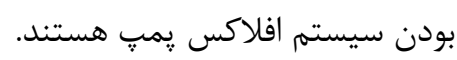

فراوانى جدايههاى موراكسلا كاتاراليس به تفكيك نمونههاى بالينى، r مورد از خلط بيماران مبتلا به عفونت تنفسى تحتانى

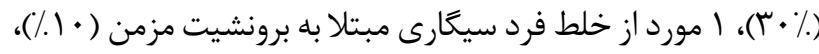

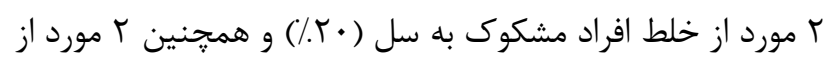
نمونه سواب ناحيه هييوفارنكس و اوروفارنكس بالغين داراى عفونت

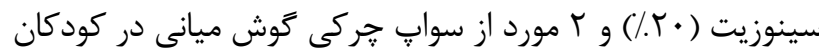

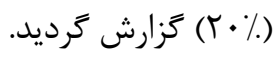

\section{نتايج مقاومت آنتىبيوتيكى با روش انتشار در ديسك}

بر اساس استانداردو · CLSI Y ، از • • ب باكترى جداشده از

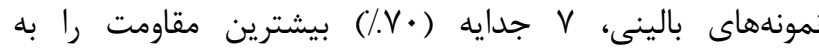
آنتىبيوتيكهاى ينىسيلين، آميىسيلين، اميكاسين، جنتامايسين، كلرامفنيكل، تتراسايكلين، سييروفلوكساسين، سفازولين، سفتازيديم و مقاومت كمتر نسبت به ترىمتويريم/سولفامتاكسازول كزارش

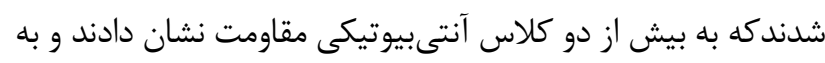
عنوان سويه هاى MDR انتخاب زرديدند. تمامى سويه هاى باكترىهاى مورد نظر به آنتىبيوتيكهاى، آموكسىسيلين اكلاولانيك اسيد (كواموكسى كلاو)، آزيترومايسين و اريترومايسين

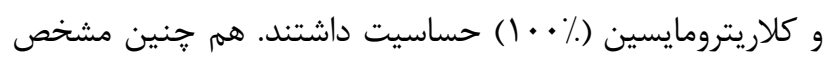
كرديد كه هيج سويهاى از موراكسلا كاتاراليس به همة آنتىبيوتيكها مقاوم نشده و آنتىبيوتيكهاى آموكسىسيلين/

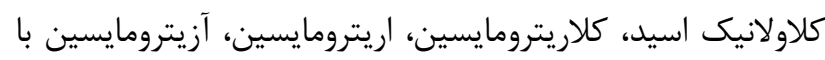
حساسيت • • 1\% مىتوانند موثر باشند.

\section{نتايج تعيين هويت موراكسلا كاتاراليس جدا شده با تست PCR} بعداز اندازهخيرى قطر هاله عدم رشد، V جدايه مقاوم به بيش از دو كلاس آنتىبيوتيكى، براى انجام بقيئ مراحل اين مطالعه انتخاب شدند كه با استفاده از يرايمر اختصاصى 19SrRNA جدايههاى براى 


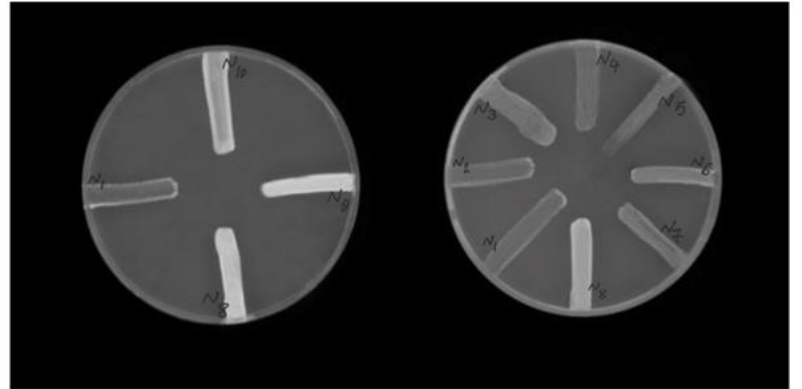

(ب)

(الف)

شكل r. نتايج بررسى فنوتييى پمب افلاكس، هرخط مربوط به يك جدايه از

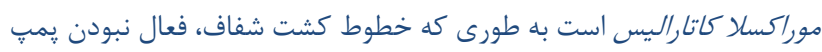

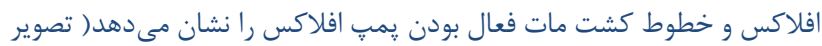

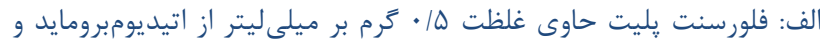

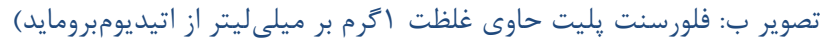

نتايج وابستخى مقاومت آنتىبيوتيكى به فعاليت يمٍ افلاكس با استفاده از مهار كنندهُ يمي افلاكس

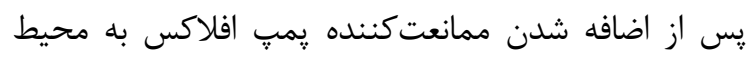
كشت، آنتىبيوتيكهاى، سفازولين، سفتازيديم، سييرو-فلوكساسين، كلرامفنيكل، تتراسايكلين داراى عملكرد ضد باكتريايى بيشترى شدند (شكل)). اين مقاومت آنتىبيوتيكى جد/يههای موراكسلا كاتاراليس وابسته به يمٍ افلاكس بود؛ زيرا منطقهُ ممانعت كننده از رشد آنها نسبت به آنتىبيوگرام اول (عدم حضور مهاركننده) تغيير ييدا كرده و قطر هالهٔ عدم رشد در حضور مهار كننده بيشتر شد. لذا اين مسئله، نشان از تاثير يمب افلاكس در مقاومت آنتىبيوتيك دارد.

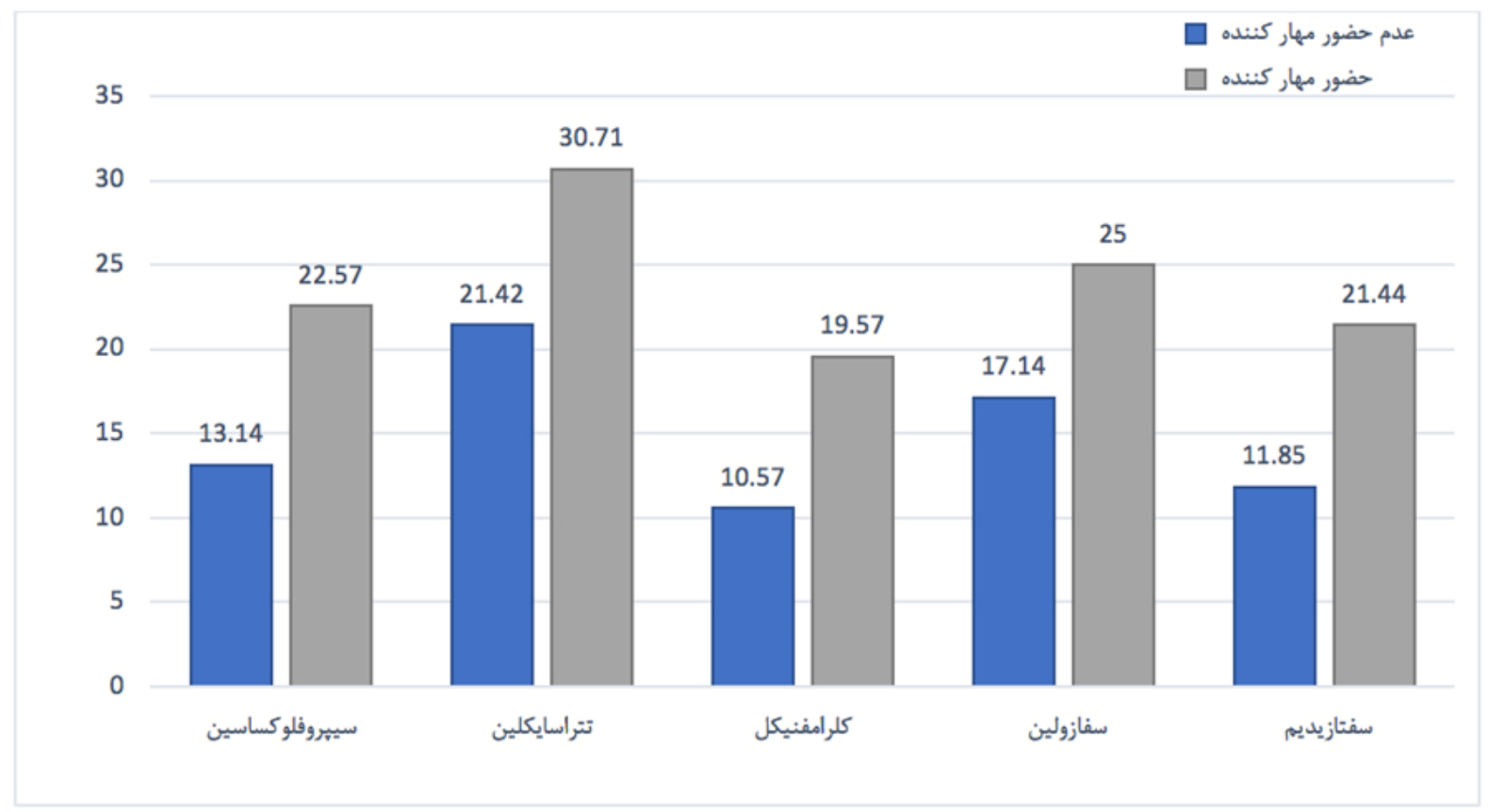

شكل r. مقايسه الكوى مقاومتى جدايهاى موراكسلا كاتاراليس نسبت به آنتىبيوتيك هاى سييروفلو كساسين، تتراسايكلين، كلرامفنيكل، سفازولين و

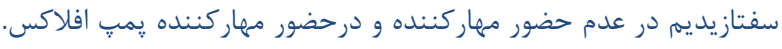

درصد مشاهده شد. زنهاى پيمي افلاكس در هر V جدايه مقاوم به

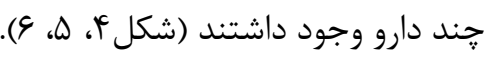

\section{oprm acrb acra نتايج بررسى فراوانى زن هاى}

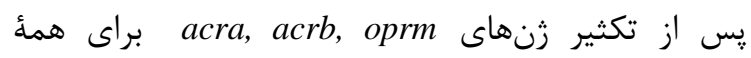
جدايههاى موراكسلا كاتاراليس مقاوم به جند إنداي دارو، محصولات

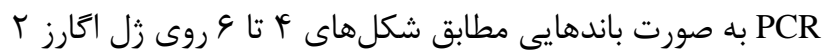




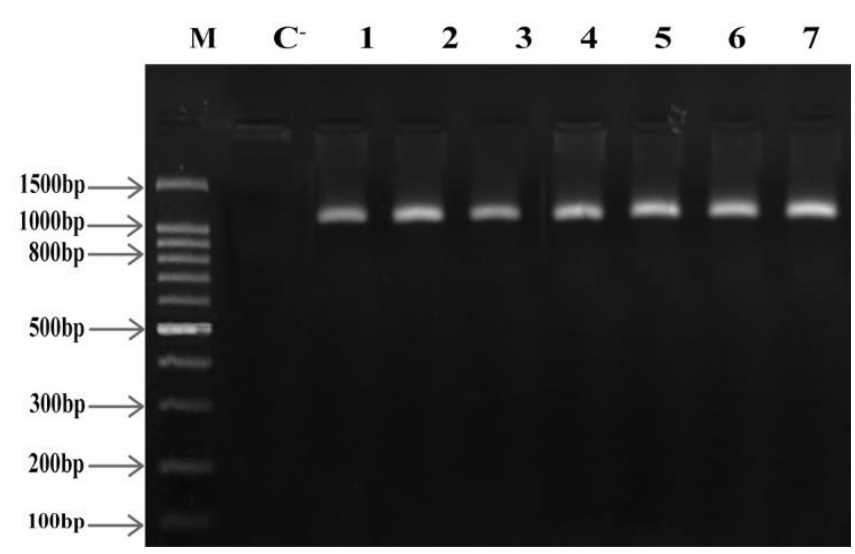

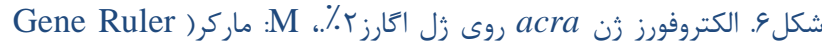
100 bp

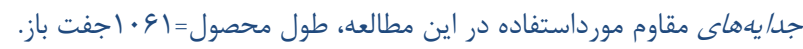

\section{بحث}

موراكسلا كاتاراليس در سالهاى اخير به عنوان يك عامل مهرم در عفونتهاى تنفسى تحتانى و فوقانى گزارش شده است و

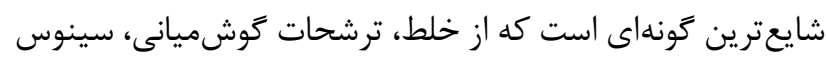
و سواب حلق و دهان قابل جداسازى است ( ه). در اين مطالعه از

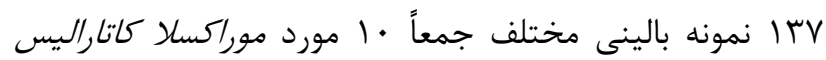

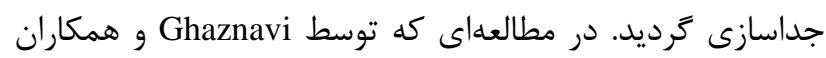

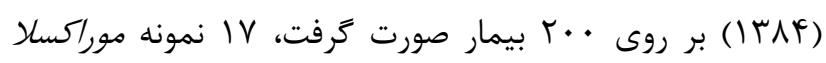

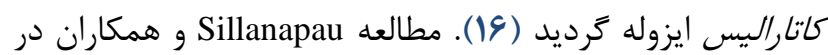

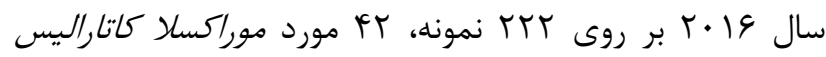
جداسازى گرديد (IV). در تحقيقات Miravitlles كه بر روى بيمار مبتلا به بيمارى مزمن انسدادى ريه صورت گرفته بود، از 1 ر

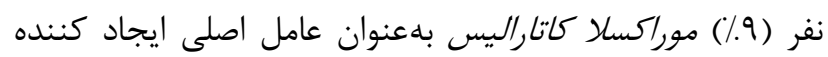
بيمارى ايزوله گرديد (1) (1). مقادير فوق با مقدار باكترى ايزوله شده در اين تحقيق (• إنمونه) تا حدودى همخوانى دارد. ولى اختلاف

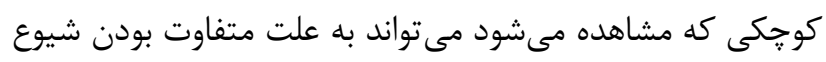
باكترىها در نواحى جغرافيايى مختلف باشد.

نتايج حاصل از حساسيت آنتىبيوتيكى نشان داد كه بيشترين مقاومت مربوط به آنتىبيوتيكهاى جنتامايسين، آميكاسين، ينى رئى سيلين G، آميىسيلين، سفتازيديم، سفازولين، تتراسايكلين،

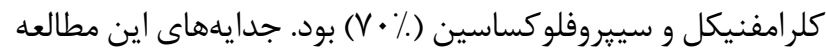
به آنتىبيوتيك ترى متويريمى- سولفامتاكسازول مقاومت حدواسط

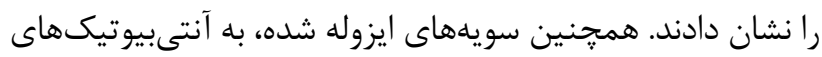

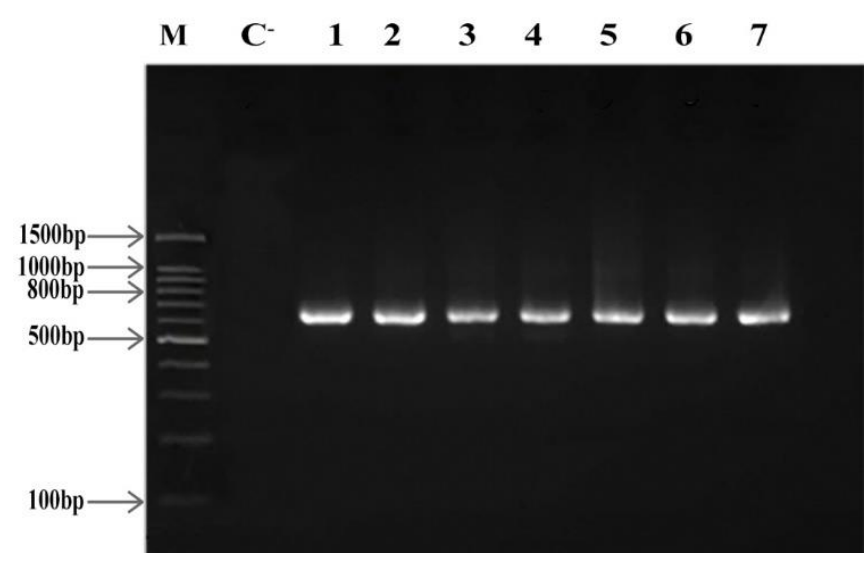

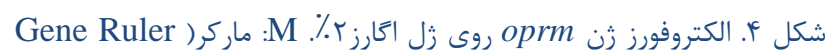
100 bp

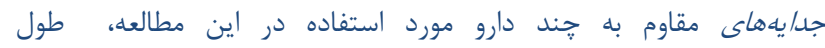

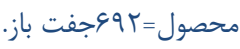

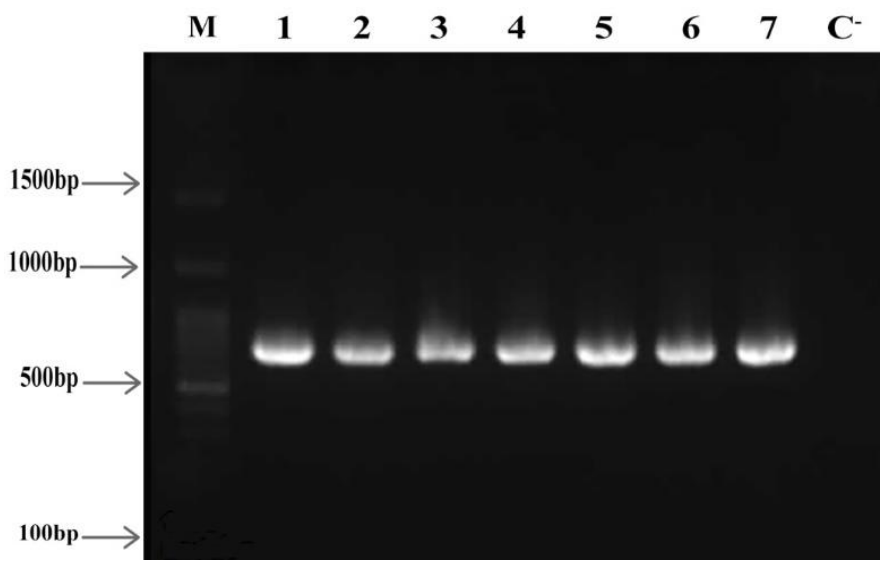

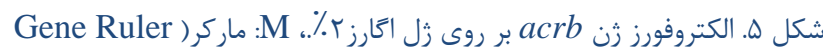
100 bp

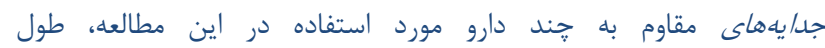

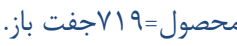

همجنين بر طبق آزمون مربع كاى ارتباط معنى دارى در

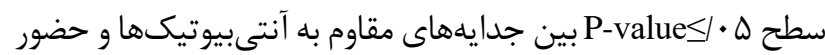
زنهاى oprm acrb acra يمب افلاكس مشاهده شد و براى جهار آنتىبيوتيك كوآموكسى كلاو، اريترومايسين، ازيترومايسين و و كلاريترومايسين كه در همه جدايهها حساس ززارش گرديد، ارتباط معنادارى در سطح ه • P-value 
محدود است و مطالعات در اين خصوص پييشينهُ زيادى ندارد. بر

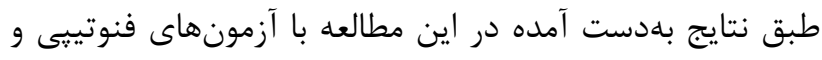

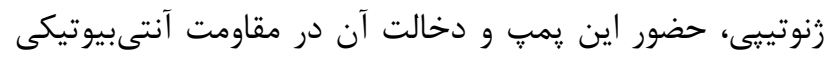

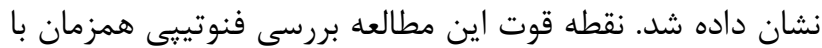

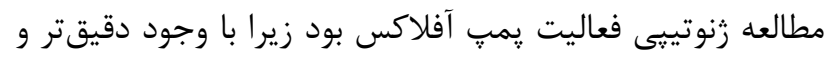

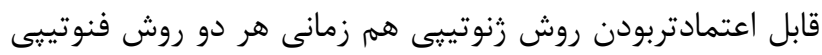

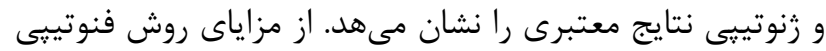
مى توان به كشتسريع و تشخيص كم هزينهتر پِي إفلاكس اشاره

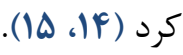

همجنين روش كارتويل در كنار تعيين فعاليت فنوتيبى پمب

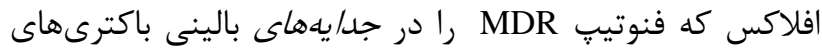

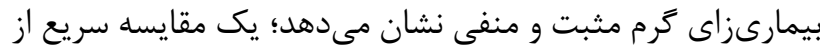
فعاليت افلاكس را كه در نتيجأ جهش مئهاى ايزوزنيك در آزمايشكاه،

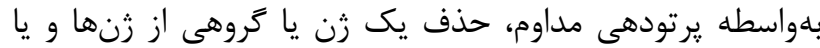
رشد سوئ باكترى در شرايط مختلف (دما، PH و غيره) ايجاد مىشود، فراهم مى كند (IF). (IF) بر اساس شواهد، فعاليت سيستمهاى يُمٍ افلاكس درموراكسلا كاتاراليس قبلاً بهصورت كامل، شناسايى نشده بود. باتوجه به به بهائ مطالعات جند سال اخير و نتايج حاصل از PCR سويههاى جدا

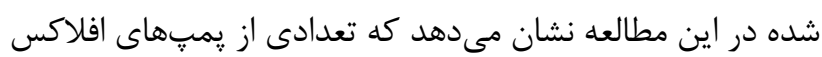

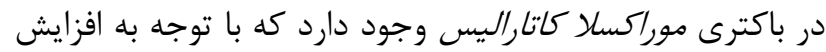
مقاومت موراكسلا كاتاراليس و افزايش بيمارىهاى تنفسى مطالعهأ اين زنها در بررسى الكوى درمانى بيماران عفونى و تنفسى

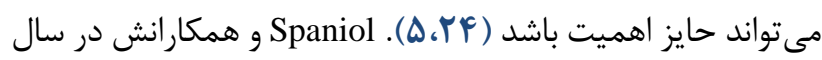
ها • ب با استفاده ازدادههاى توالى يابى براى سويهء موراكسلا كاتاراليس نشان دادند كه پِمٍ هاى افلاكس Acr و Mtr

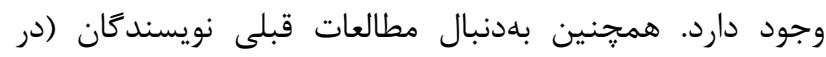

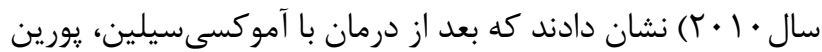

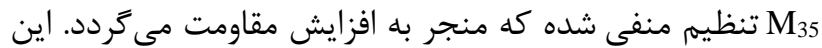

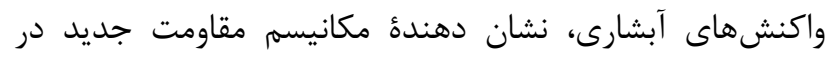

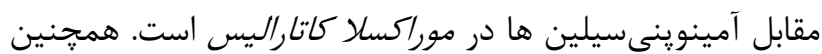
نقش يمب جريان AcrAB-OprM در مقاومت آنتىبيوتيكى با هوران

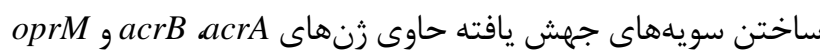
در كونه M.catarrhalis O33E در آن مطالعه مشخص شده بن بود

مهار كنندة فنيل آلانين - آرزنين- بتانفتيل آميد دى هيدروكلرايد

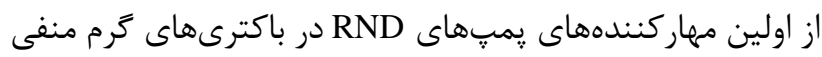

آزيترومايسين، اريترومايسين، كلاريترومايسين و آموكسى سيلين

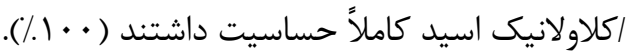

مطالعات مختلفى براى بررسى ميزان مقاومت آنتىبيوتيكى

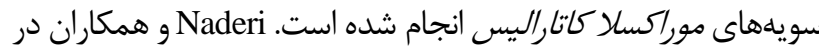

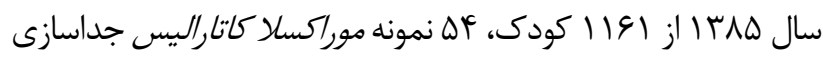
نموده و الكوى مقاومت آنتىبيوتيكى بررسى كردند كه بيشترين

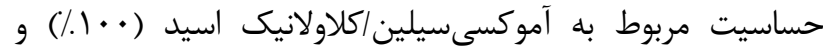
بالاترين مقاومت به بنىسيلين ( • (1/) كزارش كرديد (19). مطالعه Bandet و همكارانش در سال Y Y Y نشان داد همدٔ سويههاى موراكسلا كاتاراليس جداسازى شده به آنتىبيوتيكهاى

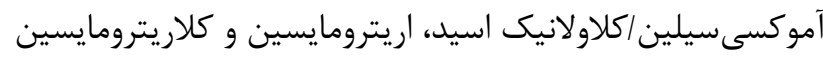

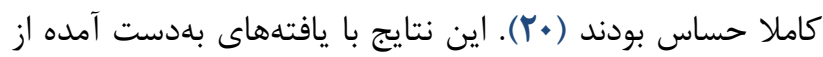

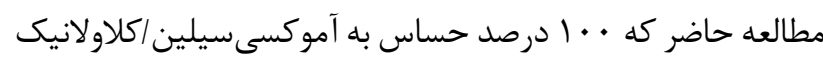
اسيد و ماكروليدها بود، مطابقت دارد. همجنين با مطالعة مشابهى إنى

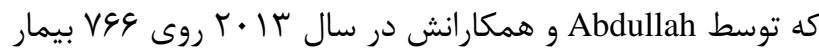
صورت كرفت، وج سويه موراكسلا كاتاراليس جداسازى كرديد، كه

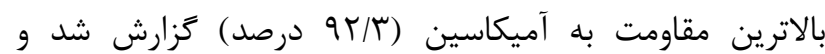
بيشترين حساسيت به آموكسىسيلين/كلاولانيك اسيد ( •. (./)

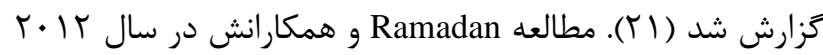

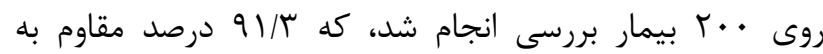

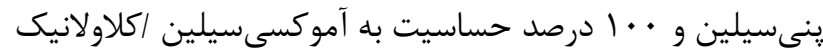

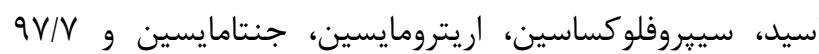
درصد به تتراسايكلين گزارش شد (Y (Y). از مقايسٔ مطالعه حاضر و ساير مطالعات منتشر شده در قلمرو شيوع سويههاى مقاوم به آنتىبيوتيك باكترى موراكسلا كاتاراليس

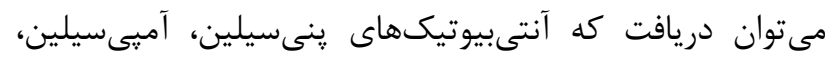

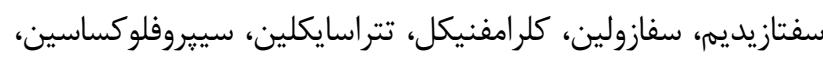

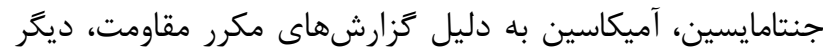

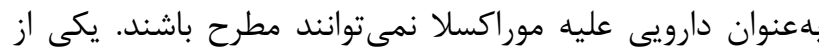

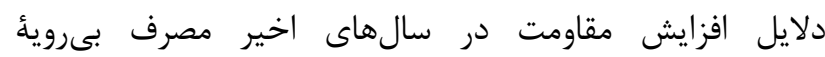

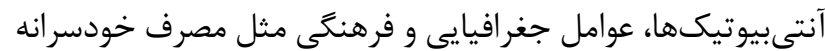
آنتىبيوتيكها و در دسترس بودن آنتىبيوتيكها است كه هريك فيك

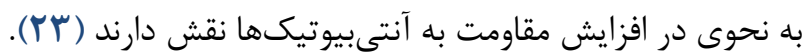
سيستم تراوشى جند دارويى AcrAB-OprM اولين يُمٍ تحت

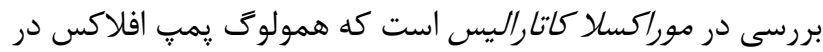
باكترى /شريشيا كولى است (ه، YF). تعداد مطالعات انجام شده در مورد زنهاى يُمٍ افلاكس در موراكسلا كاتاراليس نسبتا 
وابسته به يمب افلاكس و مهاركننده اين يمٍ در باكترى موراكسلا

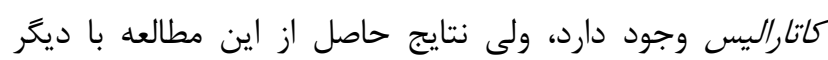

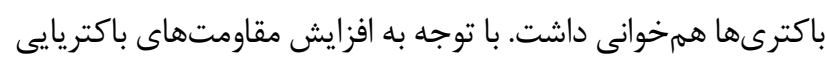

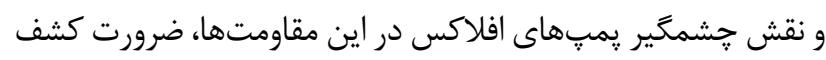

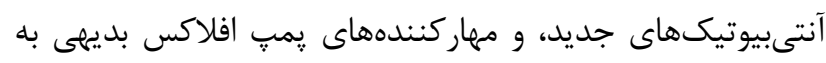

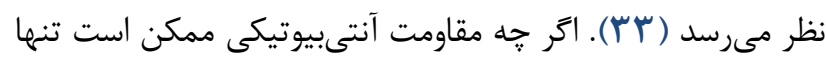

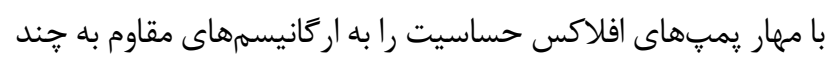

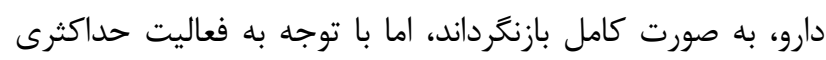
يمب افلاكس در • V٪ سويههاى اين مطالعه، همكارى و ارتباط بيان

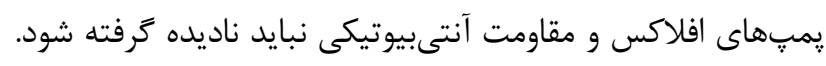

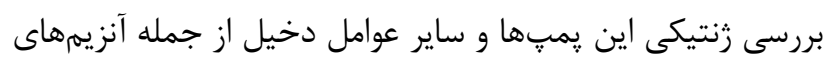
بتالاكتاماز نيز در مطالعات آتى، ضرورى بنهن بنظر مير عرسد.

\section{نتيججه كيرى}

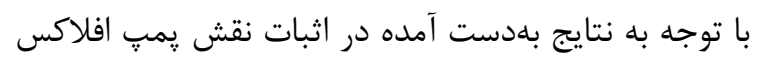

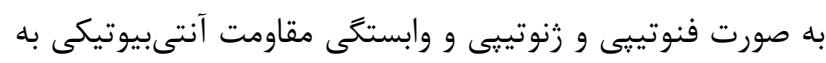

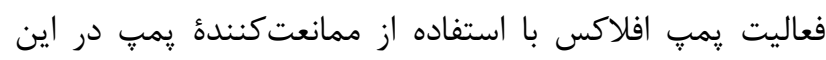

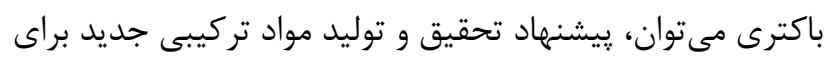

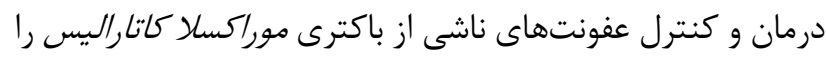

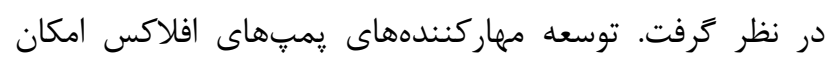

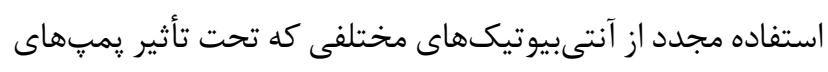

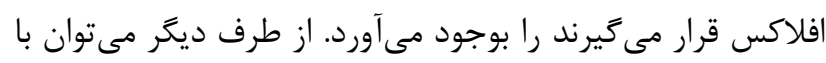

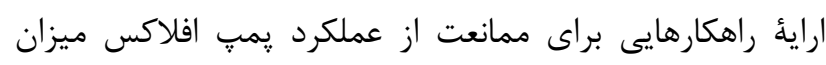

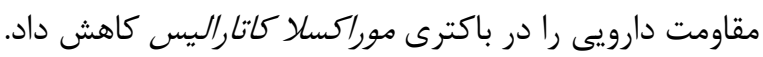

\section{سياسگزارى}

بدين وسيله مراتب قدرانى و تشكر خود را از تمام كسانى كه إنه در طول اجراى اين بروهش مرا يارى كردند اعلام مىنمايم. شايان

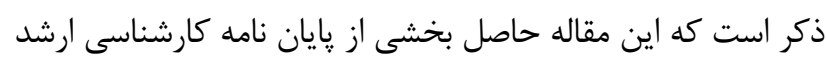

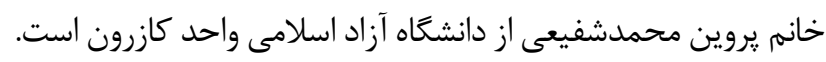

\section{تعارض در منافع}

در انجام مطالعه حاضر، نويسندكان هيجَّونه تضاد منافعى نداشتهاند.

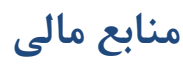

منابع مالى اين تحقيق توسط، نويسندًان تامين شده است.
است (YY.rV) (YY). مطالعات نشان مىدهد كه با مختل كردن

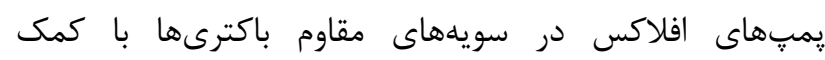

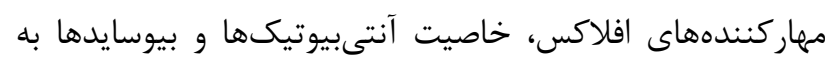

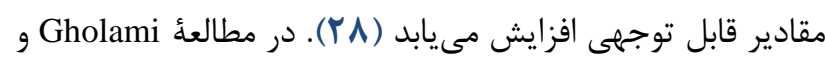

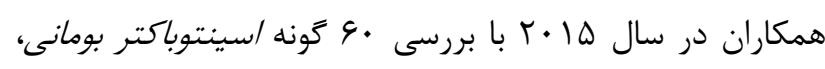

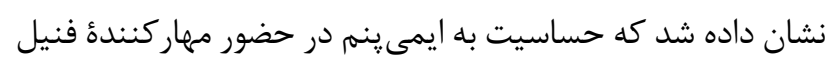

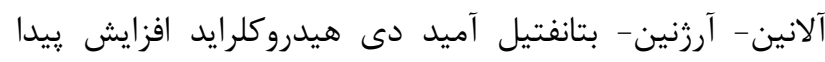

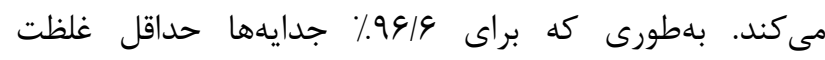

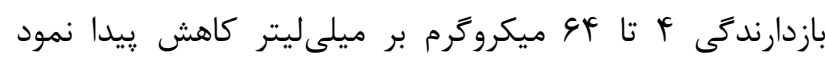

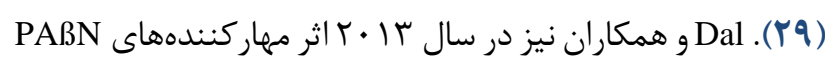

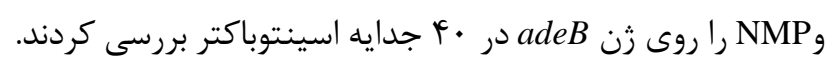

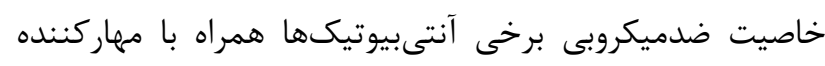

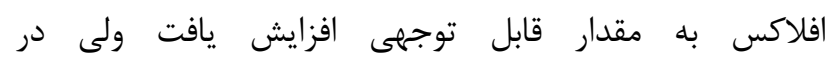

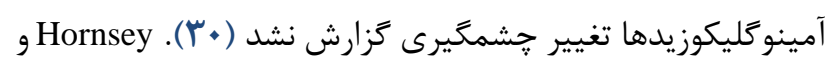

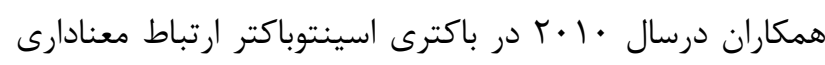

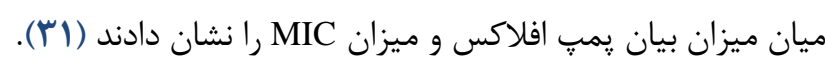

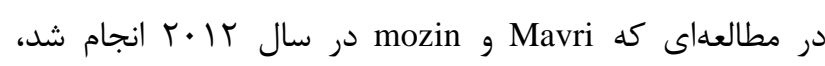

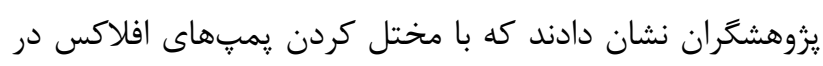

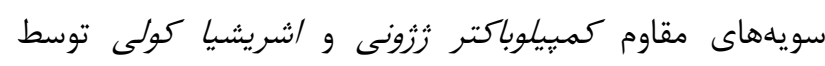
مهاركنندههاى يمب افلاكس خاصيت ضدميكروبى آنتىبيوتيكها

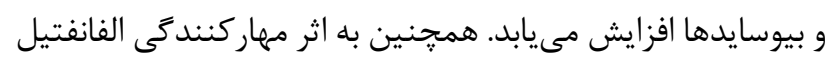

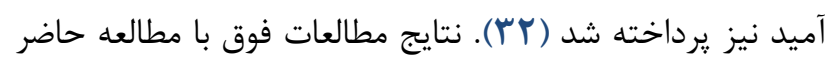

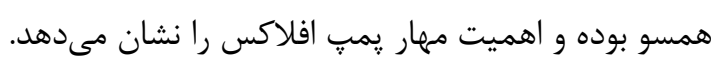
در مطالعهُ ديخرى Sonnet و همكاران در سال r ا • ب نشان دادند

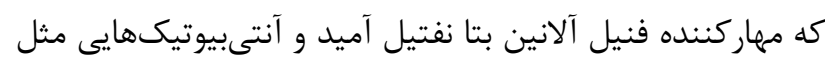

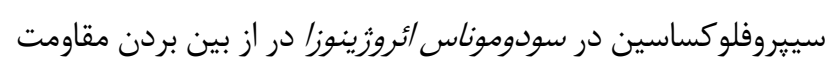

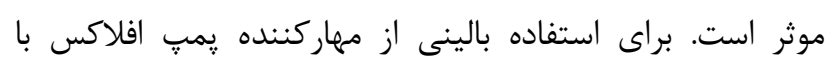

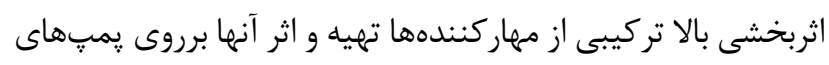

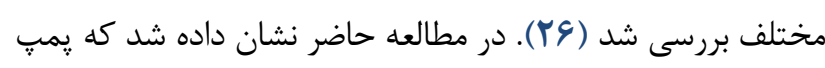
افلاكس مىتواند در كاهش مقاومت به فلوروكينولونها

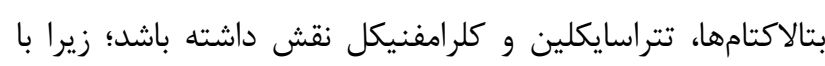

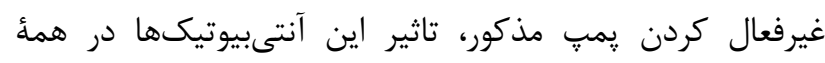

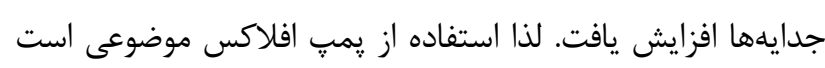

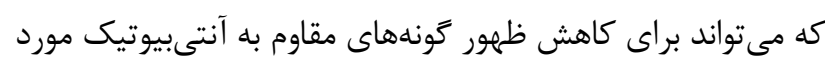

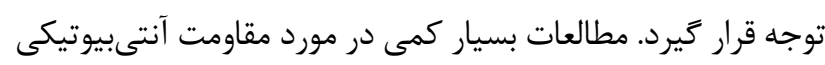




\section{Referance}

1. Enright MC, McKenzie H. Moraxella (Branhamella) catarrhalis. Clinical and molecular aspects of discovered pathogen. J Med Microbiol 1997; 46(5): 360-71 [DOI:10.1099/00222615-46-5-360] [PMID]

2. Tamang MD, Dey S, Makaju RK, Jha BK, Shivananda PG, Bhramadatan KN. Prevalence of Moraxella catarrhalis infections of the lower respiratory tract in elderly patients. Kathmandu Univ Med J (KUMJ). 2005;3(1):39-44

3. Murphy TF, Parameswaran GI. Moraxella catarrhalis, a human respiratory tract pathogen. Clin Infect Dis.2009;49(1): 124-131 [DOI:10.1086/599375] [PMID]

4. Wald ER. Sinusitis. Pediatr Ann 1998 Dec; 27(12):818-8 [DOI:10.3928/0090-4481-19981201-08] [PMID]

5. Spaniol V, Bernhard S, Aebi CH. Moraxella catarrhalis AcrAB-OprM Efflux Pump Contributes to Antimicrobial Resistance and Is Enhanced during Cold Shock Response. Antimicrob Agents Chemother. 2015; 59(4): 1886-1894. [DOI:10.1128/AAC.03727-14] [PMID] [PMCID]

6. Sun J, Deng Z, Yan A. Bacterial multidrug efflux pumps: mechanisms, physiology and pharmacological exploitations. Biochemical and biophysical research communications. 2014;453(2):254-67. [DOI:10.1016/j.bbrc.2014.05.090] [PMID]

7. Webber M, Piddock L. The importance of efflux pumps in bacterial antibiotic resistance. J Antimicrob Chem. 2003;51(1):9-11 [DOI:10.1093/jac/dkg050] [PMID]

8. Du D,Wang-kan X,Neuberger A,W.Van Veen H, M.Pos K,J. V. Piddock L et al. Multidrug efflux pumps: structure, function and regulation. Nature Reviews Microbiology. 2018;16(9):523-539 [DOI:10.1038/s41579-018-0048-6] [PMID]

9. Nikaido H, Takatsuka Y. Mechanisms of RND multidrug efflux pumps. Biochim Biophys Acta.2009;1794(5):769781. [DOI:10.1016/j.bbapap.2008.10.004] [PMID] [PMCID]

10. Valadkhani F, Zeighami H. Efflux pump systems in bacteria. Lab Diagn. 2016; 8(33): 35-43. [In Persian]

11. Stavri M, Piddock LJ, Gibbons S.Bacterial efflux pump inhibitors from natural sources. $\mathrm{J}$ of antimicrobial chemotherapy.2016;59(6):1247-60. [DOI:10.1093/jac/dkl460] [PMID]

12. Melendez PR, Johnson RH.Bacteremia and septic arthritis caused by Moraxella catarrhalis. Reviews of Infectious Diseases. 1991;13(3): 428-9. [DOI:10.1093/clinids/13.3.428] [PMID]

13. Clinical and Laboratory Standards Institute (CLSI). Performance standards for antimicrobial susceptibility testing; twenty-four informational supplement. M100S21. Wayne Pa: CLSI; 2016.

14. Martins M, McCusker MP, Viveiros M, Couto I, Fanning S, Pagès JM, Amaral L. A simple method for assessment of MDR bacteria for over-expressed efflux pumps. The open microbiology journal. 2013; 7:72 [DOI:10.2174/1874285801307010072] [PMID] [PMCID]

15. Martins M, Santos B, Martins A, Viveiros M, Couto I, Cruz A. An instrument-free method for the demonstration of efflux pump activity of bacteria. In Vivo. 2006; 20(5): 657-664.

16. Ghaznavi Rad A, Zarei R, Jafari A, Palizwan M.R, Jourabchi A, Moeini L, Rafiei M. Prevalence of Moraxella catarrhalis and risk factors for it in patients with respiratory infections referred to Valiasr and Amirkabir hospitals in Arak.Yafte. 2005;7(4):117-122

17. Sillanpass S, Oikarinen S,Sipila M,kramna L, Rautianen M,Huhtala $\mathrm{H}$ et al.Moraxella catarrhalis Might Be More Common than Expected in Acute Otitis Media in Young Finnish Children. J Clin Microbiol.2016; 54(9): 23732379. [DOI:10.1128/JCM.01146-16] [PMID] [PMCID]

18. Miravitlles M, Espinosa C, FernandezLaso E, Martos JA, Maldonado JA,Gallego M. Relationship between bacterial flora in sputum and functional impairment in patients with acute exacerbations of COPD. Study Group of Bacterial Infection in COPD. Chest.1999; 116(1):40-6 [DOI:10.1378/chest.116.1.40] [PMID]

19. Naderi H,Bakhshaei M,qzvini K,Zamanian A,Haghighi $\mathrm{ZH}$. Prevalence of moraxlacataralysis carriers in the nasopharynx of healthy children under 6 years of age in kindergartens in Mashhad and determination of antibiotic resistance pattern in isolated moraxella catarrhalis.Iran $\mathrm{J}$ Otorhinolaryngol.2007;18(46):169-173

20. Bandet T, Whitehead S, Blondel-Hill E, Wagner K, Cheeptham N. Susceptibility of clinical Moraxella catarrhalis isolates in British Columbia to six empirically prescribed antibiotic agents.Can J Infect Dis Med Microbiol.2014;25(3):155-158 [DOI:10.1155/2014/370964] [PMID] [PMCID]

21. Abdullah FE, Ahuja KR, Kumar H. Prevalence and emerging resistance of Moraxella catarrhalis in lower respiratory tract infections in Karachi. J Pak Med Assoc. 2013;63(11):1342-1344. [PubMed]

22. Ramana B V,Chaudhury. Antibiotic sensitivity pattern of Moraxella catarrhalis at a tertiary care hospital. IJPLS.2012;3(7):1805-6

23. Kafilzadeh F, Farsimadan F. Investigating multidrug efflux pumps in relation to the antibiotic resistance pattern 
in Escherichia coli strains from patients in Iran. Biomedical Research 2016; 27 (4): 1130-1135

24. Spaniol V, Wyder S, Aebi C. RNA-Seq-based analysis of the physio- logic cold shock-induced changes in Moraxella catarrhalis gene expression. PLoS One.2013;8(12):10.1371

[DOI:10.1371/annotation/a6e15b35-386c-4b0a-9de96fea091e9088]

25. Shriram V, Khare T, Bhagwat R, Shukla R, Kumar V. Inhibiting Bacterial Drug Efflux Pumps via PhytoTherapeutics to Combat Threatening Antimicrobial Resistance. Front Microbiol.2018;9(2990) [DOI:10.3389/fmicb.2018.02990] [PMID] [PMCID]

26. Sonnet P, Izard D, Mullié C. Prevalence of efflux mediated ciprofloxacin and levofloxacin resistance in recent clinical isolates of Pseudomonas aeruginosa and its reversal by the efflux pump inhibitors 1-(1naphthylmethyl)-piperazine and phenylalanine arginine $\beta$ naphthylamide. Int J Antimicrobial .2012; 39:77- 80 [DOI:10.1016/j.ijantimicag.2011.08.005] [PMID]

27. 27. Barrero MAO, Pietralonga P a. G, Schwarz DGG,Silva A, Paula SO, Moreira M a. S.Effect of the inhibitors phenylalanine arginyl 3 naphthylamide (PAßN) and 1-(1naphthylmethyl)-piperazine (NMP) on expression of genes in multidrug efflux systems of Escherichia coli isolates from bovine mastitis. Res Vet Sci.2014;97(2):176-81. [DOI:10.1016/j.rvsc.2014.05.013] [PMID]

28. Moazzen Z, Eslami G, Hashemi A, Yousefi Nojookambari N. Efflux Pump Inhibitor Carbonyl Cyanide 3-Chlorophenylhydrazone (CCCP) Effect on the Minimum Inhibitory Concentration of Ciprofloxacin in Acinetobacter baumannii Strains. Arch Clin Infect Dis.2018;13(2): e59644 [DOI:10.5812/archcid.59644]

29. Gholami M, Hashemi A, Hakemi-Vala M, Goudarzi H, Hallajzadeh M. Efflux pump inhibitor phenylalaninearginine B-Naphthylamide effect on the minimum inhibitory concentration of imipenemin Acinetobacter baumannii strains isolated from hospitalized patients in Shahid Motahari Burn Hospital, Tehran, Iran. Jundishapur J Microbiol. 2015; 8(10): 1-7 [DOI:10.5812/jjm.19048] [PMID] [PMCID]

30. Dal T, Aksu B, Pages J.M and Over-Hasdemir U. Expression of the adeB gene and responsiveness to 1 (1naphthylmethyl)-piperazine and phenylalanyl arginylbnaphthylamide in clinical isolates of Acinetobacter baumannii. J Antimicrob Chemother.2013; 1-3. [DOI:10.1093/jac/dks511] [PMID]

31. Hornsey M, Ellington MJ, Doumith M, Thomas CP, Gordon NC, Wareham DW, et al. AdeABC-mediated efflux and tigecycline MICs for epidemic clones of Acinetobacter baumannii. J Antimicrob Chemother 2010; 93-65:1589 [DOI:10.1093/jac/dkq218] [PMID]

32. Mavri A. Moz ina S.S. Involvement of efflux mechanisms in biocide resistance of Campylobacter jejuni and
Campylobacter coli. J Med Microbiol.2012; 61: 800-8. [DOI:10.1099/jmm.0.041467-0] [PMID]

33. Sharma A, Gupta VK, Pathania R. Efflux pump inhibitors for bacterial pathogens: From bench to bedside. Indian J Med Res.2019; 149(2):129-145 [DOI:10.4103/ijmr.IJMR_2079_17] [PMID] [PMCID] 